Factors Affecting Technology Acceptance During COVID-19 Crisis ...

Dr/ Niveen Ezzat Aly

\title{
Factors Affecting Technology Acceptance During COVID-19 Crisis in Egyptian Higher Education
}

\begin{abstract}
Niveen Ezzat Aly
Assistant Professor in Cairo University, Faculty of Commerce, Business Administration
\end{abstract}

\section{Abstract}

1.1.Purpose

The research aims to explore factors that affected behavior of faculty members in Egyptian public universities regarding their acceptance and use of social network tools (SNTs) in teaching during the period of the COVID-19 outbreak.

\subsection{Design/methodology/approach}

A structured questionnaire has been adopted to survey and collect data from 224 faculty members in Cairo University where the population was 241 . The nine constructs were measured using a five-point Likert scale. Researcher conducted Descriptive Analysis, Exploratory Factor Analysis (EFA), Confirmatory Factor Analysis (CFA), and Structural Equation Model (SEM).

\subsection{Findings}

The findings revealed that TAM's core variables, perceived ease of use and perceived usefulness, have been proven to be antecedent factors that have affected acceptance of teaching with

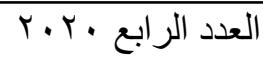

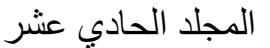


Factors Affecting Technology Acceptance During COVID-19 Crisis ...

Dr/ Niveen Ezzat Aly

technology in the Egyptian public universities. Privacy, and Institutional Support were not identified as determinants factors associated with TAM. Infrastructure and Device Access were partially considered as external factors affecting the model.

\subsection{Research limitations/implications}

The research findings will provide insights to the various stakeholders such as educators, management, and researchers on the adoption and use of SNTs from a faculty's point of view that will add knowledge to help in practical implementation. This research also helps shed light on the characteristics of the higher education environment in Egypt, as an example of a developing country. Future research may well focus on comprehensive review addressing variety of teaching-learning domains, learning technologies and types of users to identifying additional external factors that could further explain acceptance and usage of various learning technologies in Egypt.

Keywords: Extended TAM, Faculty Members, Higher Education, Crisis Containment, COVID-19 Crisis.

\section{Introduction}

Unexpectedly, the COVID-19 crisis forced schools and educational institutions to adapt distance teaching and work from home, as a result using multiple teaching methods of social networks in all educational institutions including higher education. Teaching from home for faculty members was

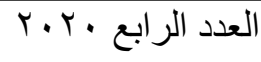

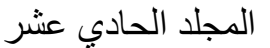


Factors Affecting Technology Acceptance During COVID-19 Crisis ...

Dr/ Niveen Ezzat Aly

mandatory to comply with the recent regulations to manage and containment the damages of the crisis.

The behavior of faculty members directly affects the quality of the educational process, therefore determining the factors affecting the acceptance and use of technology in teaching is of clear importance. Many faculty members in Egyptian universities faced the issue for the first time as the traditional method was face-to-face classes.

The importance of the study lies in the identification of determinants that influence the adoption of social network tools (SNTs) in teaching, because there is an imperative for a rapid and efficient shift from the traditional teaching methods to teach from a distance. Adopting distance education has become a straightforward path accepted by the competent authorities to develop a general policy for the higher education sector in Egypt. Additionally, all stakeholders have notified that academic year (2020- 2021) will be blended, a mix ofane-learning and the conventional teaching methods.

In various studies, TAM is considered one of the commonly used models concerned with analyzing human actions when dealing with different technical methods to assess the essence of individuals' propensity to adopt and use technology means. (Matemba, E. D., Li, G., Gogan, I. C. W., \& Maiseli, B. J. 2020). This model has undergone modifications over the years (Bylieva,

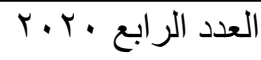

المجلد الحادي عشر 
Factors Affecting Technology Acceptance During COVID-19 Crisis ...

Dr/ Niveen Ezzat Aly

D., Bekirogullari, Z., Lobatyuk, V., \& Nam, T. 2020), as many external variables have introduced that affect the behavior of individuals when they use different technological means. SNTs have been defined in previous studies from different points of view but in this research, SNTs are any social network platform with reliable tools that facilitates communication and improves the learning environment. Social network platforms are currently widespread around the world, the use of social media has become a lifestyle for younger generations. Several studies assured that using social media in teaching increased the students ' interest, participation, engagement, and creativity (Stainbank, L. and Gurr, K.-L. 2016, Magraner, JSB., Romos, RL.2020, Khodabandeh, F., 2020, Atabek, O., 2020, Khodabandeh, F., 2020). Unfortunately, pre-coronavirus Egyptian higher education plans did not include a formal systematic process to rely on these resources to get potential benefits. The study promotes multidisciplinary research grounded on the intersection of three disciplines of social media, higher education administration, and crisis management.

The study was limited to Cairo University, as it is the first university established in Arab Republic of Egypt and also for its influential role in higher education not only in Egypt but in all Arab countries. Also, limited to the Faculty of Commerce for data gathering convenience, reaching all faculty members was available since contacting them was via the official website,

$$
\text { العدد الرابع · r. ا }
$$

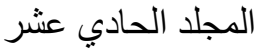


Factors Affecting Technology Acceptance During COVID-19 Crisis ...

Dr/ Niveen Ezzat Aly

official emails, official WhatsApp groups, and face to face. After extensive review to the topic literatures published in different environments, the research questions were as follows:

- What external factors may have an effect on the adoption and usage of SNTs?

It was a necessity to identify the obstacles that keep the teaching staff from pursuing education from a distance (work from home) via different SNTs, so the knowledge, experiences, and competencies are not wasted without benefiting from it. This study's contribution stems from the fact that it leads to the integration of academic as well as practical knowledge.

\section{Research Problem}

The research problem lies in determining the factors affecting the use of technology from the viewpoint of the faculty members. Unfortunately, most of them do not have prior experience nor the knowledge needed to use technological tools in teaching. Also, the determination of these factors is affected by environmental variables. Accordingly, the factors agreed upon in previous studies must be tested and studied in light of the Egyptian environment and culture. Besides, the lack of sufficient time for a gradual shift from the traditional method to the distance education method would lead to some difficulties that may affect the adoption and use of SNTs. Based on the above the research problem is to answer the following question:

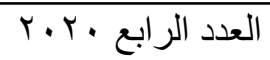


Factors Affecting Technology Acceptance During COVID-19 Crisis ...

Dr/ Niveen Ezzat Aly

What are the external factors that may affect the adoption and usage of SNTs?

\section{Research Population}

The research population represented in all faculty members and the teaching assistants who taught during the period of the COVID-19 outbreak. The compliance with the need for a rapid shift to teaching from home after the university president issued a decision in this regard was very important. That was during the second semester of the 2019-2020 academic year. Based on the academic schedules for the second semester of 2019-2020 prepared by the Faculty Schedules Department, the total number was 241individuals. Therefore, a comprehensive inventory method was adopted due to the small size of the research population,224questionnaireswere valid, which was $92.9 \%$

\section{Research Objectives}

The main purpose of this research is to identify the external factors that may affect the acceptance of the SNTs, this was done by examining the research model of Aburagaga, I., Agoyi, M., \& Elgedawy, I. (2020), to find out how consistent the results of the research conducted in Libya are with the results of the study in the Arab Republic of Egypt.

The comprehensive research objective is:

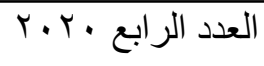

المجلد الحادي عشر 
Factors Affecting Technology Acceptance During COVID-19 Crisis ...

Dr/ Niveen Ezzat Aly

Identify the external factors that may affect the adoption and usage of SNTS

The detailed research objectives are:

1. Determine the effect of Privacy on PE of SNTs.

2. Determine the effect of Privacy on PU of SNTs.

3. Determine the effect of Infrastructure on PE of SNTs.

4. Determine the effect of Infrastructure on PU of SNTs.

5. Determine the effect of Institutional Support on PE of SNTs.

6. Determine the effect of Institutional Support on PU of SNTs.

7. Determine the effect of Access Devices on PE of SNTs.

8. Determine the effect of Access Devices on PU of SNTs.

9. Determine the effect of PE on the Attitude towards the Use of SNTs.

10.Determine the effect of PE on the PU of SNTs.

11.Determine the effect of PU on Attitude towards the Use of SNTs.

12.Determine the effect of PU on Behavioral Intention of Using SNTs.

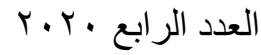

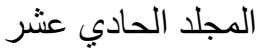


Factors Affecting Technology Acceptance During COVID-19 Crisis ...

Dr/ Niveen Ezzat Aly

13.Determine the effect of Attitude on Behavioral Intention of Using SNTs.

14.Determine the effect of Behavior Intention on the Actual Use of SNTs.

\section{Research Importance}

Research derives its scientific significance from being as a genuine research on both the country level (Egypt) and on the higher educational level.

A systematic literature review investigated the TAM in higher educational domains indicated that the majority focused on students' acceptance, and only a small percentage of $6 \%$ was concerned with the study of teachers and faculty members. Also, the predominant application to the type of technology used was on mobile technology, while a very small percentage was interested in studying SNTs. Additionally, the majority of studies originated from countries located in the Asian continent, the Middle East region received only one research in Egypt (Granić, A., \& Marangunić, N. (2019).

The importance of the study represented the quick switching of educational institutions to expand their education delivery methodologies to incorporate online, remote, and flexible learning, which is a strategic response to the COVID-19 outbreak. Online education requires massive investment in different aspects like educational infrastructure, platforms, and 
Factors Affecting Technology Acceptance During COVID-19 Crisis ...

Dr/ Niveen Ezzat Aly

tools. Unfortunately, public universities in developing countries do not have such requirements thus, using social media was the available alternative in the short term. That switching needs a rapid and efficient transformation from faculty members to change their traditional way of teaching(face-to-face) to teach from a distance by using various technological tools such as social media tools. It is critical to identify the real factors that influence their behavior towards adopting the use of these technologies so that the expertise and competencies they have are not wasted. Also, the behavior of faculty members has a direct impact on the quality of the educational process, so improving their level of performance will necessarily lead to improving the level of education. Additionally, identifying the factors that affect their behavior will help to overcome any obstacles that may exist, and also help to develop a comprehensive strategy to cope with the current events. There is also great importance for the application sector, given the essential role of universities in bringing about comprehensive development especially in developing countries. Higher education is one of the key drivers of growth performance, prosperity, and competitiveness in national and global economies. Universities and other institutions not only deliver tertiary education and ongoing skills training, but also provide a validity research environment that produces innovations with valuable commercial applications.

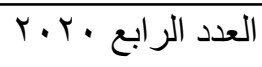

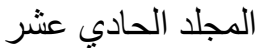


Factors Affecting Technology Acceptance During COVID-19 Crisis ...

Dr/ Niveen Ezzat Aly

\section{Literature Review}

After reviewing many studies related to the extended technology acceptance model, especially in Arab countries, the researcher decided to adopt the proposed model from one of the recent studies that took place in a sister Arab country, Libya. As it brings the two countries together, beside the common borders, the sharing of language and some customs and traditions.

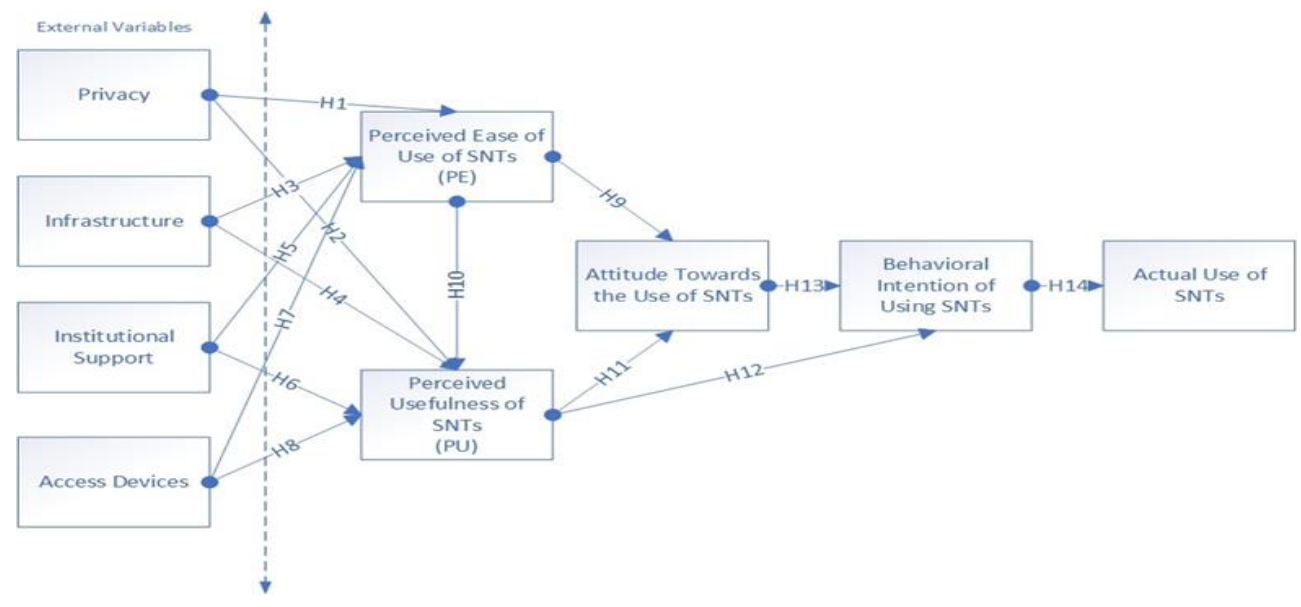

Figure (1) The Research Model

Adapted from I. Aburagaga et al, 2020

7.1.Managing the crisis (Containment/ Damage limitation)

There are many definitions of crisis management, one of them as three phases; preventative measures, crisis management plans, and post-crisis evaluations (Coombs, W. T., \& Holladay, S. J. (Eds.). 2011). However, the definition most widespread and

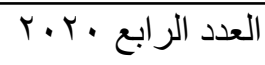

المجلد الحادي عشر 
Factors Affecting Technology Acceptance During COVID-19 Crisis ...

Dr/ Niveen Ezzat Aly

accepted by researchers is that it consists of five phases; Signal Detection, Preparation/Prevention, Containment/Damage Limitation, Recovery, and Learning (Mitroff, I. I., \& Pearson, C. M. 1993). The crisis containment phase aims to limit the spread of negative harms to persons, organizations, or the environment that have not yet been affected. This strategic goal is achieved by establishing procedures and adhering to them. COVID-19 is a global crisis with not enough time to prepared before its occurrence, so have to move swiftly to the crisis response phase (crisis mood). It was a necessity to take decisive measures to contain the COVID-19 crisis and reduce its damages related to three areas; public safety, financial loss, and inevitably reputation damage. This phase is including two steps: (1) the initial crisis response and (2) reputation repair and behavioral intentions (Nguyen, T.T., 2019). The first step towards crisis containment is to assess the situation by quickly gathering as much accurate information as possible. (Andrianopoulos, A., 2016). The next step is to communicate with the public and stakeholders. It is vital because stakeholder perception is critical to a company's success since faculty members (as one group of the stakeholders) are among the parties directly influencing the damages containment of the crisis. They can reduce the three inter-related threats by carrying out the teaching process efficiently and effectively. A quick, well-structured response shows that the faculty is in control and safeguards the reputation

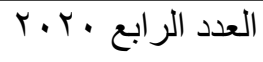

المجلد الحادي عشر 
Factors Affecting Technology Acceptance During COVID-19 Crisis ...

Dr/ Niveen Ezzat Aly

and trust. In the response phase, traditional models and paradigms of management do not work. They must be verified, redefined, and adapted to those extremely critical conditions (Bieńkowska, A., Tworek, K. and Zabłocka-Kluczka, A., 2020). A recent study concluded that one of the influential factors for success in managing the crisis is that employees have a high degree of flexibility by accepting the variables accompanying and adapting quickly to it. Resilient employees can help their organization rebound to normal functioning following a crisis (Kim, Y., 2020).

In this research, the shifting from the traditional face-to-face classes to virtual classes was the procedures needed to limit the damages, and due to the lack of the required infrastructure, reliance on social network tools was the only available solution to contain the three damage.

\subsection{Extensional of the TAM}

TAM is one of the most cited models for predicting the technology acceptance that used in different theoretical studies. (Vanduhe, V. Z., Nat, M., \& Hasan, H. F. (2020). Many of the previous studies have dealt with the determinants (external variables) that affect the TAM that considered as an extensional of the original model (Davis, F. D. 1986).A recent systematic analysis of literature that underlies TAM study in the field of education, one of the findings indicated that the percentage of

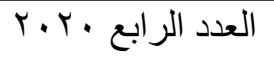

المجلد الحادي عشر 
Factors Affecting Technology Acceptance During COVID-19 Crisis ...

Dr/ Niveen Ezzat Aly

adopting the original TAM was $49 \%$, the modified TAM was $13 \%$ and extended TAM was $38 \%$ of the identifies publications. Other findings related to different sample groups of participants in the selected studies indicated that only $6 \%$ of all sample groups were faculty members and teachers' participant(Granić, A., \& Marangunić, N. (2019).

There is no agreement about these external variables research concluded that the external factors were the price willing to pay, past use, curiosity, and age (Manis, K. T., \& Choi, D. 2019). Others investigated the effects of cognitive gratification, hedonic gratification, and personal integrative gratification (Aburub, F., \& Alnawas, I. 2019). Hsiao, C. H., \& Yang, C. (2011) suggested that PU and self-efficacy related to learning can have powerful effects on usage than PE. In a recent study, the researchers suggested new external variables; Task Technology Fit, Social Influence, and Social Recognition that affected the PU and PE (Vanduhe, V. Z., Nat, M., \& Hasan, H. F. (2020).

\section{a) Privacy and SNTs}

Privacy described as the right to regulate the size and nature of data and information that he/she wishes to share with others. (Mohamed, N., \& Ahmad, I. H. (2012), Hu, Z., Ding, S., Li, S., Chen, L., \& Yang, S. (2019). Adoption intention of fintech services for bank users: An empirical examination with an extended technology acceptance model viewed on the basis that

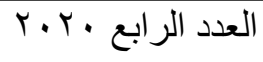

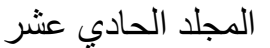


Factors Affecting Technology Acceptance During COVID-19 Crisis ...

Dr/ Niveen Ezzat Aly

it is personal information that no one has the right to know that will be a threat to the security of that personal information (Lallmahamood, M. (1970). Some studies have shown that people are willing to share private information with others if there is an economic or social benefit that he/ she will receive in return (Keith, M. J., Thompson, S. C., Hale, J., Lowry, P. B., \& Greer, C. 2013, Li, H., Sarathy, R., \& Xu, H. 2010). Some studies concluded that privacy had strongly affected the users' acceptance, that users perceived with high privacy violation would consider it riskier to adopt the information technology, and that would eventually affect the users' behaviors (Miltgen, C. L., Popovič, A., \& Oliveira, T. 2013). Lin, C. A., \& Kim, T. (2016) their result was that privacy affected all the TAM variables: PU, PE, Attitude, and Behavior. Sobaih, A. E. E., et al. (2016), in their study conclusion was the top concerns for the actual use of social media as teaching and learning tools, were the threats of disclosure to their personal life and tracking their activities. A recent study indicated a significant correlation between Phone IPA use and privacy concerns, and a significant association between Home IPA use and privacy concerns (Liao, Y., Vitak, J., Kumar, P., Zimmer, M., \& Kritikos, K. (2019). Keith, M. J., Thompson, S. C., Hale, J., Lowry, P. B., \& Greer, C. (2013) concluded that privacy has an impact on perceived privacy risk and hence, it will affect both Intention to use and Actual Behavior. Some studies have proven the opposite of the

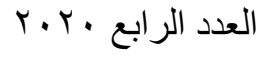

المجلد الحادي عشر 
Factors Affecting Technology Acceptance During COVID-19 Crisis ...

Dr/ Niveen Ezzat Aly

above, as they have confirmed that privacy does not affect the acceptance and use of technology (Pradhan, A., et. al. 2018, Fruchter, N., Liccardi, I. 2018). Moorthy, A. E., Vu, K.-P.L. (2015) found that the effect of privacy does not stand alone, that privacy and security considerations draw on a complex interplay of technical operations, users' experiences, and mental models, and contextual cues.

Other studies concluded that using SNTs in learning was considered a waste of time and effort, and considered a threat to privacy, and also reduces the quality of the traditional education process (Manca, S., \& Ranieri, M. (2016). However, developing security plans and procedures can address concerns related to security and trust (Culnan, M. J., \& Armstrong, P. K. (1999). And due to the presence of many open-source SNTs, the effect of the privacy variable will have an impact on the extent of acceptance and use of social media in education (Tan, X., Qin, L., Kim, Y., \& Hsu, J. 2012). There is general agreement in many studies regarding the impact of privacy, and its impact on the PU and the PE of using SNTs (M. T. Braun, 2013). Many studies considered Privacy as one of the external factors that affect the PU and PE (Keith, M. J. et al. 2013, Rafique, H. et al.2020, Al-Maroof, R. S. et al. 2020, and Lallmahamood, M. 1970, Aburagaga, I., Agoyi, M., \& Elgedawy, I. 2020). Based on the review of the previous studies referred to above, the hypotheses associated with this point are as follows:

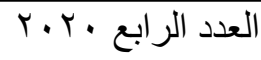

المجلد الحادي عشر 
Factors Affecting Technology Acceptance During COVID-19 Crisis ...

Dr/ Niveen Ezzat Aly

H1: Privacy has a negative and significant effect on PE of SNTs.

H2: Privacy has a negative and significant effect on PU of SNTs.

b) Infrastructure and SNTs

Infrastructure is defined as the critical networks and applications that an organization requires to function properly (Manca, S., \& Ranieri, M. 2017). Infrastructure includes networking systems, networking equipment, computer facilities, and electricity (Ursavaş, Ö. F., Yalçın, Y., \& Bakır, E. 2019, Ameen, N., \& Willis, R. 2017). Alhashmi, S. F., Salloum, S. A., \& Abdallah, S. (2019), defined the infrastructure as the critical success factors for implementing artificial intelligence projects, they concluded that Infrastructure factor has a positive impact on perceived usefulness and on perceived ease of use. Kamal, S. A., Shafiq, M., \& Kakria, P. (2020) and Ammenwerth, E. (2019) found that Facilitating Conditions (FC) positively influence the intention to use/ the actual use, with consideration (FC) included the technological infrastructure since combining three basic constructs: perceived behavioral control, facilitating conditions, and compatibility. Recent research found that Facilitating Conditions directly affect PE, and directly affect Attitude (Fearnley, M. R., \& Amora, J. T. 2020) .

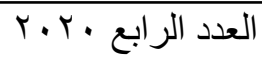

المجلد الحادي عشر 
Factors Affecting Technology Acceptance During COVID-19 Crisis ...

Dr/ Niveen Ezzat Aly

The quality of internet connectivity, including internet speed and efficiency, is considered to be an essential factor to build sufficient infrastructure that needed to provide an adequate basis for the use of SNTs in universities. In addition, lack of access to the internet, poor internet services, high connectivity prices, lack of facilities offered by universities, and lack of awareness about how to use the system are factors that could limit the use of SNTs in learning and education (Aburagaga, I. et al. 2020). Research studies that focused on the impact of infrastructure on the acceptance and use of SNTs in higher education are considered few and rare, and most of them have focused on the Internet as the most important component of infrastructure (Awa, H. O., Ojiabo, O. U., \& Emecheta, B. C. (2015). The study looked at the use of social media as an important teaching and learning method in higher education in developing countries; like Egypt, founded that Infrastructure which consisted of (IT policy, IT support, and Internet access) is affected the Behavior negatively (as a barrier) although, the Intention is positive regarding the use of social media (Sobaih, A. E. E., Moustafa, M. A., Ghandforoush, P., \& Khan, M. (2016). Based on the review of the previous studies referred to above, the hypotheses associated with this point are as follows:

H3: Infrastructure has a positive and significant effect on PE of SNTs.

العدد الر ابع • r. الع

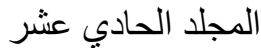


Factors Affecting Technology Acceptance During COVID-19 Crisis ...

Dr/ Niveen Ezzat Aly

H4: Infrastructure has a positive and significant effect on PU of SNTs.

\section{c) Institutional Support and SNTs}

Institutional support (IS) is characterized as activities and programs that help provide the required setting for a high-quality online education service (Cishe, E. N. 2014). One of the studies showed that educational institutions must have the ability to shift from the traditional method of teaching to electronic education, taking into account all stakeholders including students, faculty members, employees, and researchers (Abdullah, M. S., \& Toycan, M. 2017).Previous studies revealed a wide variety of situational advisors that are common in contemporary organizations, such as the availability of training and supporting personnel, management, and consultants. (IS) is known to be a construction that represents assistance or obstacles to behaviors related to external conditions. (Park, N., Rhoads, M., Hou, J., \& Lee, K. M. 2014).A recent study investigated the effects of (IS) on the PU and PE, suggesting that the more organizational assistance is offered, the greater PU and PE for SNTs (Aburagaga, I., Agoyi, M., \& Elgedawy, I. (2020). Another research investigated the use of social media as an effective teaching-learning tool in higher education in Egypt, proved that relying on social media did not receive priority attention from faculty members and officials authority due to the lack of policies based on integration between IT and the use of social

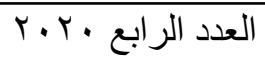

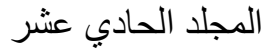


Factors Affecting Technology Acceptance During COVID-19 Crisis ...

Dr/ Niveen Ezzat Aly

media in teaching (Sobaih, A. E. E., Moustafa, M. A., Ghandforoush, P., \& Khan, M. (2016). Further research has shown that both individual factors, such as anxiety and selfefficacy, and institutional factors, such as institutional support and voluntariness, are strongly linked to perceived ease of use (PE), perceived usefulness (PU) and actual use of systems (Park, N., Rhoads, M., Hou, J., \& Lee, K. M. (2014). Based on the review of the previous studies referred to above, the hypotheses associated with this point are as follows:

H5:Institutional Support has a positive and significant effect on PE of SNTs.

H6: Institutional Support has a positive and significant effect on PU of SNTs.

\section{d) Access Device and SNTs}

Access Device is defined as any device used to explore and use the SNTs mobile devices with Internet access are considered the most popular one among the other types like PC, Tablet, and Notebook. Due to frequent app updates, recent mobile technological advancement has made using mobile much easier than before (Au, M., \& Lam, J. (2015). A study of extended TAM on the mobile technology acceptance of educators in the higher education industry in the United States found that perceived resources have a positive direct effect on PU, PE, Attitude, and Behavioral Intention to use the mobile technology.

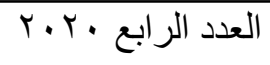$$
\text { المجلد الحادي عشر }
$$ 
Factors Affecting Technology Acceptance During COVID-19 Crisis ...

Dr/ Niveen Ezzat Aly

Access Device was defined in research as a sub-factor of perceived resources, it was limited to the definition of mobile technology that including any portable computing device with touch-screen features, capable of running applications and connecting to the Internet via wireless and wireless data networks, the results confirmed there is no significant difference between the different types of devices. (Halawi, L., \& Pires, D. (2019). Another study defined access device as a sub-factor of facilitating conditions concluded that they could not identify interdependence between suitability of IT tools (Device Access) and its acceptance and use (Kurilovas, E., \& Kubilinskiene, S. (2020).One more study expanded the basic TAM by incorporating perceived access barriers as a third assumption about technology adoption that illustrates attitudes towards technology, demonstrating that the use of other beliefs (i.e. perceived access barriers) in the sense of the Internet can dramatically influence user attitudes. (Porter, C. E., \& Donthu, N. (2006). A research study has investigated the factors affecting university students' adoption and use of m-learning, the results confirmed that system accessibility was the least factor affecting the student's acceptance (Park, S. Y., Nam, M. W., \& Cha, S. B. (2012). Although, there are some limitations in Access Device that hinder the actual use of the device the continuous development in technology resulted in enhancing to be a friendly user. Most research studies confirmed that PU and PE are always

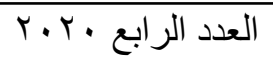

المجلد الحادي عشر 
Factors Affecting Technology Acceptance During COVID-19 Crisis ...

Dr/ Niveen Ezzat Aly

critical factors in the adoption of the devices (Negahban, A., \& Chung, C. H. (2014).Based on the review of the previous studies referred to above, the hypotheses associated with this point are as follows:

H7: Access Devices has a positive and significant effect on PE of SNTs.

H8: Access Devices has a positive and significant effect on PU of SNTs.

\section{e) $\underline{P E, P E \text { and } S N T S}$}

In general, there is almost agreement in previous studies regarding the reliability and validity of the basic factors composing the TAM; Perceived Ease of Use (PE) and Perceived Usefulness (PU) that it can be relied upon in explaining people's behavior towards their acceptance and use of technology (Scherer, R., Siddiq, F., \& Tondeur, J. (2019), (Al-Emran, M., Mezhuyev, V., \& Kamaludin, A. (2018), (Weerasinghe, S. (2017), Abdullah, F., \& Ward, R. (2016), Imtiaz, M. A., \& Maarop, N. (2014) .A recent systematic literature review indicated that TAM and its different versions represent a credible model for facilitating the assessment of diverse learning technologies (Granić, A., \& Marangunić, N. (2019). TAM's core variables, PE and PU, have been proven to be antecedent factors affecting the acceptance of learning with technology (Al-Qaysi, N., Mohamad-Nordin, N., \& Al-Emran, M. (2020), and (Rahimi,

$$
\text { العدد الر ابع • r. T }
$$


Factors Affecting Technology Acceptance During COVID-19 Crisis ...

Dr/ Niveen Ezzat Aly

B., Nadri, H., Afshar, H. L., \& Timpka, T. (2018). Since the model was developed by Davis, most studies have confirmed that $\mathrm{PE}$ has a strong influence on a person's attitude and Behavior Intention toward technology use (Alhashmi, S. F., Salloum, S. A., \& Abdallah, S. (2019), (Kamal, S. A., Shafiq, M., \& Kakria, P. (2020), and (Alghizzawi, M., Habes, M., Salloum, S. A., Abd, M., Ghani, C. M., \& Shaalan, K. (2019). Also, most literature confirmed the effects of PE on PU, that PE has a positive effect on PU hence, PU is a crucial determinant and convenient to implement into any particular technology adoption. An only recent study suggested that intention to use Virtual Reality (VR) is positively influenced by perceived usefulness (PU) and PE has no effect on the use of VR (Sagnier, C., Loup-Escande, E., Lourdeaux, D., Thouvenin, I., \& Valléry, G. (2020).Most previous studies in TAM agreed that PU has a strong influence on (BI) and the Attitude in relation to the acceptance of technology, whether using it over the Internet or without it. (Venkatesh, V. and Davis, F. D. (2000). Literature review confirmed that a person must first perceive the benefit of using technology in order to be able to perceive the ease of use, which ultimately affects the attitude and behavior (Aburagaga, I., Agoyi, M., \& Elgedawy, I. (2020). Other research investigated the acceptance of telemedicine services through an extended technology acceptance model, the findings were PU positively influence the intention of use, and PE has no effect on the

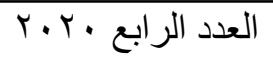

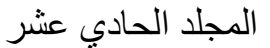


Factors Affecting Technology Acceptance During COVID-19 Crisis ...

Dr/ Niveen Ezzat Aly

Intention of use (Kamal, S. A., Shafiq, M., \& Kakria, P. (2020). Based on the review of the previous studies referred to above, the hypotheses associated with this point are as follows:

H9: PE has a positive and significant effect on attitude towards the use of SNTs.

H10:PE has a positive and significant effect on PU of SNTs.

H11:PU has a positive and significant effect on attitude towards the use of SNTs.

H12: PU has a positive and significant effect on behavior intention towards the use of SNTs.

\section{f) Attitude and SNTs}

Attitude plays an important role in TAM, considered as an intermediate variable between the outcome of the interaction of PU and PE on the one hand, and the behavioral intention associated with the use of SNTs on the other hand $(\mathrm{Wu}, \mathrm{B} .$, \& Chen, X. (2017), and (Lorenzo-Romero, C., Alarcón-del-Amo, M. D. C., \& Constantinides, E. (2014). A recent study identified the critical success factors for implementing artificial intelligence (AI) projects in the Dubai government United Arab Emirates (UAE) health sector, the results confirmed that Attitude towards use affects positively the behavioral intention to implement artificial intelligence projects in the healthcare sector (Alhashmi, S. F., Salloum, S. A., \& Abdallah, S. (2019). Most previous

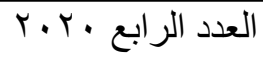

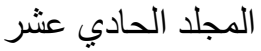


Factors Affecting Technology Acceptance During COVID-19 Crisis ...

Dr/ Niveen Ezzat Aly

studies confirmed that Attitude towards the use of SNTs is affected by PE and PU together, and Attitude effects on Behavioral Intention of Using SNTs (Pai, F. Y., \& Yeh, T. M. (2014). In general, attitude towards using SNTs has been regarded as the degree to which an individual perceives a positive or negative feeling related to SNTs. (Granić, A., \& Marangunić, N. (2019), and (Vanduhe, V. Z., Nat, M., \& Hasan, H. F. (2020).Based on the review of the previous studies referred to above, the hypothesis associated with this point is as follows:

H13: Attitude has a positive and significant effect on behavioral intention to use SNTs.

\section{g) Behavior Intention and SNTs}

Webster (1972) defined Behavioral Intention (BI) as the degree to which a person has formulated consciousness plans to perform or not perform some specified future behavior. Most research on intention does not define the construct, rather the intention presented through its meaning as self-evident (e.g., Ajzen \& Fishbein, 1973; Miniard \& Cohen, 1981; Ryan, 1982). "A behavioral intention, therefore, refers to a person's subjective probability that he will perform some behavior," (Fishbein \& Ajzen, 1975, p. 288)

Recent studies in health care confirmed that (BI) to use effects positively on the Actual system used to implement artificial intelligence projects in the healthcare sector (Alhashmi, S. F.,

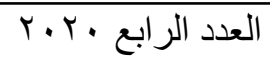

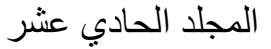


Factors Affecting Technology Acceptance During COVID-19 Crisis ...

Dr/ Niveen Ezzat Aly

Salloum, S. A., \& Abdallah, S. (2019), and the other study concluded that the four external variables affected on Behavioral Intention to use the technology (Luarn, P., \& Lin, H. H. (2005). Other study extended the applicability of the TAM in a mobile banking context, by adding one trust-based construct ("perceived credibility") and two resource-based constructs ("perceived selfefficacy" and "perceived financial cost") to the model, the results strongly support the extended TAM in predicting users' intentions to adopt mobile banking (Luarn, P., \& Lin, H. H. (2005). Behavioral Intention researches conducted in the past decade investigated the different models applied for adopting technology, on the behavioral intention theories based on beliefattitude-intention-behavior, used constructs including demographic and situational variables, cognitive variables, and personality-related variables. Several researchers proposed a new TAM (the Education Behavioral Intention Model) that focused on cognitive factors and the fit between learning and teaching styles to improve the comprehensiveness of the model (Lin, P. C., Lu, H. K., \& Liu, S. C. (2013), (Sykes., T. A., Venkatesh, V., and Gosain, S. (2009), and (Wang, Y.-S., Wu, M.-C., \& Wang, H.-Y. (2009). In an empirical study of Behavioral Intention Model, researcher extended the TAM model by integrating cognitive-oriented individual differences (including learning and teaching styles), they proposed a new theoretical framework for comprehending behavior intention in a

العدد الر ابع • r. الع

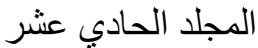


Factors Affecting Technology Acceptance During COVID-19 Crisis ...

Dr/ Niveen Ezzat Aly

better way (Hsin-Ke Lu, Peng-Chun Lin \& Alexander N. Chen (2017). Another research's result proved TAM to be a good theoretical tool to understand users' acceptance of e-learning. Elearning self-efficacy was the most important construct, followed by subjective norm in explicating the causal process in the model. (Park, S. Y. (2009). Yu, J., Ha, I., Choi, M., \& Rho, J. (2005), extended the TAM for t-commerce adoption by potential users in the home environment. Perceived enjoyment was the most important factor affecting attitude and behavioral intention toward t-commerce (Yu, J., Ha, I., Choi, M., \& Rho, J. (2005). Based on the review of the previous studies referred to above, the hypothesis associated with this point is as follows:

H14: Behavior intention has a positive and significant effect on the actual use of SNTs.

\subsection{Higher education use of SNTs}

The emergence of Web 2.0 has changed the available web technologies as well as the way people communicate and relate to one another, it was the bases requirement to develop and evolve the SNTs (Kompen, R. T., Edirisingha, P., Canaleta, X., Alsina, M., \& Monguet, J. M. (2019). There is an argument in the research literature regarding the definitions of social network tools, as these technologies and their variety of applications, user interface and social consequences tend to develop and evolve (Greenhow, C., \& Chapman, A. (2020).There are many different

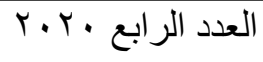

المجلد الحادي عشر 
Factors Affecting Technology Acceptance During COVID-19 Crisis ...

Dr/ Niveen Ezzat Aly

definitions for SNTs some researchers described as a connected communication platform in which participants: (1) have distinctively recognized profiles consisting of user-supplied content; (2) may make public linkages with others; and (3) may consume, create or interact with user-generated content created by their relationships to the site; (Ali, M. Y., \& Richardson, J. 2018). Others, defined as providing network analysis and communication services that help people to realize and influence the nature of the community over time. Facebook, Twitter, and emails are examples for that tools where all the information is provided by themselves (Song, Kim H.2014). Other researchers defined SNTs as a group of computer software and web-based services that enable people to interact with each other, including blogs, wikis, video conferencing, online chat, instant messaging. Finally, some researchers defined them as small web applications that allow users to connect and collaborate, for example, Facebook, Myspace, and LinkedIn (https://www.igiglobal.com/dictionary/social-networking-tools/27446).

In this research, SNTs are any social network platform with reliable tools that facilitates communication and improves the learning environment, examples are Facebook, Twitter, YouTube, Instagram, Google meet, and Blackboard.

Latest statistics indicate increases in the use of social media worldwide during the COVID-19 crisis. Beyond just reducing isolation, such widely available multimedia platforms provide

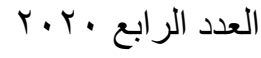

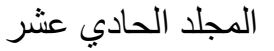


Factors Affecting Technology Acceptance During COVID-19 Crisis ...

Dr/ Niveen Ezzat Aly

educational opportunities in times of emergency (Greenhow, C., \& Chapman, A. (2020). There are several social network tools can be employed in higher education since the widespread learning environment with the advent of the second millennium (Aljawarneh, S. A. (2020). Many research findings have shown the positive effects of using social media in higher education including new opportunity for connections, collaboration, content sharing, increase the opportunity of critical thinking and participation in classes(Mazman, S.G. and Usluel, Y.K. (2010), 95.Li, J. and Greenhow, C. (2015), Greenhow, C. and Robelia, B.(2009), (Ajjan, H. and Hartshorne, R. (2008).

Other research findings have shed light to the challenges to implementing the SNTs in education for example, commercialization (the suitability of social media for education), privacy, and norms (combining learning, socializing and leisuretime spaces may also generate conflicts between learners' and teachers' goals) (Greenhow, C., \& Chapman, A. (2020). Additionally, the spread of misinformation in social media particularly during the COVID-19 crisis is a critical issue (Priebe, M. (2020). A research study has explored the use of blogs by students in UK and USA - higher education, it has been shown that their previous experience of blogs, and the perceived usefulness of blogs all influence the way in which students use blogs. Furthermore, greater use of blogs in teaching and learning activity does lead to higher perceived learning (Garcia, E.,

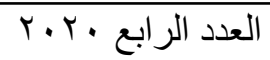

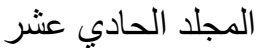


Factors Affecting Technology Acceptance During COVID-19 Crisis ...

Dr/ Niveen Ezzat Aly

Moizer, J., Wilkins, S., \& Haddoud, M. Y. (2019). Generally, adopting SNTs in teaching-learning in higher education is a double-edged sword, in order to maximize its advantages, reliance on social media must be gradually introduced, and address various challenges to develop practical solutions. Strategic plan is considered the right method to improve the quality of the educational process including all stakeholders in Egyptian higher education.

\section{Data Analysis and Results}

SPSS v.24 was used to describe the characteristics of the respondents. Before conducting Exploratory factor analysis (EFA) and Confirmatory Factor Analysis (CFA), researchers run the Exploratory Factor Analysis EFA in order to assign each item of Technology Acceptance Model (TAM) dimensions of the actual use of SNTs. After that, CFA was done. Structural Equation Modelling (SEM) was used to evaluate the proposed model and test the relationships among the constructs. More specifically, Smart PLS v.3.2.4 (Ringle et al., 2015) was used because it does not create identification problems, especially with constructs having three indicators. It also enables testing complicated relationships between different types of constructs (first and second order) more easily via smart PLS that test the PLS-SEM. (Hair et al., 2012; Henseler et al., 2009).

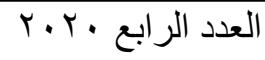

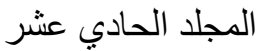


Factors Affecting Technology Acceptance During COVID-19 Crisis ...

Dr/ Niveen Ezzat Aly

\subsection{Profile of Respondents}

Table (1): Characteristics of Sample

\begin{tabular}{|c|c|c|}
\hline Sample Description & Frequency & Percentage \\
\hline \multicolumn{3}{|l|}{ 1- Gender } \\
\hline Male & 98 & 43.8 \\
\hline Female & 126 & 56.3 \\
\hline \multicolumn{3}{|l|}{ 2- Age } \\
\hline 30 years and less & 93 & 41.5 \\
\hline $31-40$ years & 51 & 22.8 \\
\hline $41-50$ years & 33 & 14.7 \\
\hline 51-60 years & 22 & 9.8 \\
\hline More than 60 years & 25 & 11.2 \\
\hline \multicolumn{3}{|l|}{ 3- Department } \\
\hline Accounting & 102 & 45.5 \\
\hline Business Administration & 99 & 44.2 \\
\hline Insurance and Actuarial & 23 & 10.3 \\
\hline \multicolumn{3}{|l|}{ 4- Education } \\
\hline Pre-Master & 73 & 32.6 \\
\hline Master & 27 & 12.1 \\
\hline $\mathrm{PhD}$ & 124 & 55.3 \\
\hline \multicolumn{3}{|l|}{ 5-Teaching } \\
\hline graduate & 129 & 57.6 \\
\hline
\end{tabular}

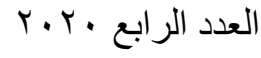

المجلد الحادي عشر 
Factors Affecting Technology Acceptance During COVID-19 Crisis ...

Dr/ Niveen Ezzat Aly

\begin{tabular}{|c|c|c|}
\hline Post-graduate & 16 & 7.1 \\
\hline Both & 79 & 35.3 \\
\hline \multicolumn{3}{|l|}{ 6- Academic Grade } \\
\hline Lecturer Assistant & 73 & 32.6 \\
\hline Lecturer & 27 & 12.1 \\
\hline Assistant Professor & 67 & 29.9 \\
\hline Associate Professor & 33 & 14.7 \\
\hline Professor & 24 & 10.7 \\
\hline \multicolumn{3}{|l|}{ 7- Profession } \\
\hline Teacher & 219 & 97.8 \\
\hline Head Department & 2 & .9 \\
\hline Vice Dean & 2 & .9 \\
\hline Dean & 1 & 0.4 \\
\hline \multicolumn{3}{|c|}{ 8- Number of Times used SNTs } \\
\hline Many times, a day & 148 & 66.1 \\
\hline Many times, a week & 39 & 17.4 \\
\hline Once a day & 8 & 3.6 \\
\hline Once a week & 29 & 12.9 \\
\hline \multicolumn{3}{|l|}{ 9- Teaching experience } \\
\hline Less than 1 year & 134 & 59.8 \\
\hline $1-2$ years & 40 & 17.9 \\
\hline $3-4$ years & 15 & 6.7 \\
\hline
\end{tabular}

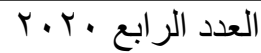


Factors Affecting Technology Acceptance During COVID-19 Crisis ...

Dr/ Niveen Ezzat Aly

\begin{tabular}{|c|c|c|}
\hline 5 years and more & 35 & 15.6 \\
\hline \multicolumn{3}{|c|}{ 10- Devices for using SNTs } \\
\hline Smart phone & 23 & 10.3 \\
\hline Laptop & 67 & 29.9 \\
\hline $\mathrm{PC}$ & 18 & 8.0 \\
\hline PC, Smart-Phone & 4 & 1.8 \\
\hline Laptop, Smart-Phone & 54 & 24.1 \\
\hline Tablet, Smart-Phone & 5 & 2.2 \\
\hline More than 2 devices & 53 & 23.7 \\
\hline \multicolumn{3}{|l|}{ 11- SNTs used } \\
\hline Facebook & 5 & 2.2 \\
\hline Facebook, YouTube & 1 & .4 \\
\hline Facebook, LinkedIn & 1 & .4 \\
\hline Facebook, WhatsApp & 5 & 2.2 \\
\hline Facebook, Others & 91 & 40.6 \\
\hline More than 2 SNTs & 121 & 54.0 \\
\hline Total & 224 & 100.0 \\
\hline
\end{tabular}

Table (1) above shows that the majority of respondents that are involved in the research are female, with the ages range between 31 to 40 years, are at accounting department. According to education, the mostly of respondents are $\mathrm{PhD}$, it also shows that

$$
\text { المجلد الحادي عشر }
$$


Factors Affecting Technology Acceptance During COVID-19 Crisis ...

Dr/ Niveen Ezzat Aly

$32.6 \%$ of respondents are Lecturer Assistant. According to profession found that $97.8 \%$ are teacher since there are one Dean and three vice Deans. Also, the mostly of respondents used SNTs many times, a day with $66.1 \%$. It also shows that $59.8 \%$ are teaching experience less than one year, $17.9 \%$ are 1-2 years. According to Devices using SNTs, 29.9\% are laptops then $24.1 \%$ laptop, smart-phone, $23.7 \%$ are more than 2 devices, $10.3 \%$ are smart-phone, $8 \%$ are PC, $2.2 \%$ are tablet, smart-phone and the last device using is PC, smart-phone with 1.8\%. Also, the majority of SNTs applications used are more than 2 SNTs with $54 \%, 40.6 \%$ are Facebook and others.

\section{Descriptive Analysis of the Research Variables:}

Table (2) shows the means and standard deviation for each of the variables used in the research. For item coding, the researcher used to PR, INF, INS, ACC, PEU, PUS, ATT, BEH and AC to refer to each sub-question of Privacy, Infrastructure, Institutional support, Access device, Perceived ease of Use, Perceived Usefulness, Attitude, Behavioral intention and Actual Used of SNTs variable respectively 
Factors Affecting Technology Acceptance During COVID-19 Crisis ...

Dr/ Niveen Ezzat Aly

\begin{tabular}{|c|c|c|c|c|c|c|c|c|c|}
\hline \multicolumn{10}{|c|}{ Table (2): I } \\
\hline \multicolumn{10}{|c|}{ Descriptive Statistics } \\
\hline \begin{tabular}{|l|} 
Construct \\
\end{tabular} & Items & $\mathrm{N}$ & Min & Max & Mean & Std. & Var & Skewness & Kurtosis \\
\hline \multirow{4}{*}{ Privacy } & PR1 & 224 & 1 & 5 & 2.61 & 1.074 & 1.154 & .135 & -.516 \\
\hline & PR2 & 224 & 1 & 5 & 2.69 & 1.238 & 1.532 & .232 & -.926 \\
\hline & PR3 & 224 & 1 & 5 & 2.95 & 1.250 & 1.563 & .024 & -.871 \\
\hline & PR4 & 224 & 1 & 5 & 2.66 & 1.161 & 1.348 & .179 & -.717 \\
\hline \multirow{3}{*}{ Infrastructure } & INF1 & 224 & 1 & 5 & 2.56 & 1.311 & 1.718 & .321 & -1.066 \\
\hline & INF2 & 224 & 1 & 5 & 2.23 & 1.208 & 1.459 & .709 & -.402 \\
\hline & INF3 & 224 & 1 & 5 & 2.67 & 1.209 & 1.461 & .314 & -.674 \\
\hline \multirow{3}{*}{$\begin{array}{c}\text { Institutional } \\
\text { Support }\end{array}$} & INS1 & 224 & 1 & 5 & 3.21 & 1.199 & 1.437 & -.214 & -.679 \\
\hline & INS2 & 224 & 1 & 5 & 2.42 & 1.184 & 1.402 & .501 & -.436 \\
\hline & INS3 & 224 & 1 & 5 & 3.13 & 1.231 & 1.516 & -.112 & -.790 \\
\hline \multirow{3}{*}{$\begin{array}{l}\text { Access } \\
\text { Devices }\end{array}$} & $\mathrm{ACC} 1$ & 224 & 1 & 5 & 2.92 & 1.180 & 1.393 & .041 & -.749 \\
\hline & $\mathrm{ACC} 2$ & 224 & 1 & 5 & 3.04 & 1.142 & 1.303 & -.061 & -.721 \\
\hline & ACC3 & 224 & 1 & 5 & 2.86 & 1.182 & 1.397 & .083 & -.757 \\
\hline \multirow{5}{*}{$\begin{array}{c}\text { Perceived } \\
\text { Ease of Use }\end{array}$} & PEU1 & 224 & 1 & 5 & 2.77 & 1.230 & 1.513 & .063 & -.957 \\
\hline & PEU2 & 224 & 1 & 5 & 3.34 & 1.060 & 1.123 & -.108 & -.751 \\
\hline & PEU3 & 224 & 1 & 5 & 3.43 & 1.035 & 1.071 & -.125 & -.624 \\
\hline & PEU4 & 224 & 1 & 5 & 3.53 & .988 & .977 & -.299 & -.289 \\
\hline & PEU5 & 224 & 1 & 5 & 3.51 & 1.020 & 1.040 & -.344 & -.375 \\
\hline \multirow{4}{*}{$\begin{array}{l}\text { Perceived } \\
\text { Usefulness }\end{array}$} & PUS1 & 224 & 1 & 5 & 3.54 & 1.087 & 1.182 & -.390 & -.512 \\
\hline & PUS2 & 224 & 1 & 5 & 3.58 & 1.060 & 1.124 & -.429 & -.411 \\
\hline & PUS3 & 224 & 1 & 5 & 3.66 & 1.047 & 1.097 & -.480 & -.332 \\
\hline & PUS4 & 224 & 1 & 5 & 3.72 & 1.099 & 1.208 & -.548 & -.422 \\
\hline Attitude & ATT1 & 224 & 1 & 5 & 3.39 & 1.166 & 1.361 & -.345 & -.557 \\
\hline
\end{tabular}

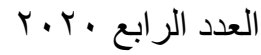

المجلد الحادي عشر 
Factors Affecting Technology Acceptance During COVID-19 Crisis ...

Dr/ Niveen Ezzat Aly

\begin{tabular}{|c|c|c|c|c|c|c|c|c|c|}
\hline & ATT2 & 224 & 1 & 5 & 3.57 & 1.065 & 1.134 & -.335 & -.552 \\
\hline & ATT3 & 224 & 1 & 5 & 3.64 & 1.019 & 1.039 & -.329 & -.481 \\
\hline & ATT4 & 224 & 1 & 5 & 3.58 & 1.060 & 1.123 & -.293 & -.529 \\
\hline & ATT5 & 224 & 1 & 5 & 3.59 & 1.129 & 1.274 & -.377 & -.602 \\
\hline \multirow{4}{*}{$\begin{array}{c}\text { Behavioral } \\
\text { intention }\end{array}$} & BEH1 & 224 & 1 & 5 & 3.74 & 1.000 & 1.000 & -.384 & -.335 \\
\hline & $\mathrm{BEH} 2$ & 224 & 1 & 5 & 3.88 & .970 & .941 & -.381 & -.658 \\
\hline & BEH3 & 224 & 1 & 5 & 3.75 & .988 & .975 & -.223 & -.789 \\
\hline & BEH4 & 224 & 1 & 5 & 3.70 & 1.000 & 1.000 & -.457 & -.162 \\
\hline \multirow{4}{*}{ Actual Use } & $\mathrm{AC} 1$ & 224 & 1 & 5 & 3.71 & 1.242 & 1.543 & -.680 & -.446 \\
\hline & $\mathrm{AC} 2$ & 224 & 1 & 5 & 3.61 & 1.174 & 1.379 & -.654 & -.287 \\
\hline & AC3 & 224 & 1 & 5 & 3.62 & 1.279 & 1.637 & -.611 & -.634 \\
\hline & $\mathrm{AC} 4$ & 224 & 1 & 5 & 3.64 & 1.155 & 1.334 & -.732 & -.143 \\
\hline \multicolumn{2}{|c|}{ Valid N (listwise) } & \multicolumn{8}{|c|}{224} \\
\hline
\end{tabular}

The analysis indicates that the means range from 2.23 to 3.88 . The standard deviation ranges from 0.970 to 1.311 which means that there is an agreement among the respondents and the variances are low because the standard deviation of any individual question is less than half of the related mean. The maximum mean value is 3.88 indicating that most respondents agree that adopting long Technology Acceptance Model (TAM) increase during COVID-19 Crisis in Egyptian Higher Education because the Educational institutions gain valuable knowledge about the student's overtime. The minimum mean value is 2.23 indicating that the majority of respondents disagree that adopting

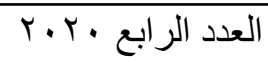

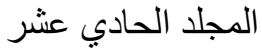


Factors Affecting Technology Acceptance During COVID-19 Crisis ...

Dr/ Niveen Ezzat Aly

long Technology Acceptance Model (TAM) strengthens the relationship between the staff members and the students. As shown in Table (2), there is a violation of normality assumption once all measurement items' skewness and kurtosis scores are not zero. However, Kline (2015) mentioned that in social science it is common to violate the normality assumption; therefore, there is no series problem to apply the parametric analyses to test the hypotheses if the skewness and kurtosis of each item within the range \pm 3 and Kurtosis within range \pm 10 .

\subsection{Exploratory Factor Analysis (EFA)}

The researcher illustrates how to conduct the Exploratory Factor Analysis (EFA) using SPSS version 24 in order to assign each item on its construct. This step should be done before testing the proposed hypotheses.

Table (3): Exploratory Factor Analysis

\begin{tabular}{|c|c|c|c|c|c|c|c|c|c|c|}
\hline Constructs & Items & Pri & Infra & Inst & Acc & PEU & PUS & ATT & BEH & $\mathbf{A C}$ \\
\hline \multirow{4}{*}{ Pri } & PR4 & .825 & & & & & & & & \\
\hline & PR3 & .810 & & & & & & & & \\
\hline & PR2 & .798 & & & & & & & & \\
\hline & PR1 & .563 & & & & & & & & \\
\hline \multirow[t]{3}{*}{ Infra } & INF2 & & .873 & & & & & & & \\
\hline & INF1 & & .870 & & & & & & & \\
\hline & INF3 & & .786 & & & & & & & \\
\hline \multirow{3}{*}{ Inst } & INS3 & & & .834 & & & & & & \\
\hline & INS1 & & & .780 & & & & & & \\
\hline & INS2 & & & .710 & & & & & & \\
\hline \multirow{3}{*}{ Acc } & ACC1 & & & & .891 & & & & & \\
\hline & ACC2 & & & & .878 & & & & & \\
\hline & ACC3 & & & & .798 & & & & & \\
\hline
\end{tabular}

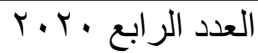

المجلد الحادي عشر 
Factors Affecting Technology Acceptance During COVID-19 Crisis ...

Dr/ Niveen Ezzat Aly

\begin{tabular}{|c|c|c|c|c|c|c|c|c|c|c|}
\hline \multirow{5}{*}{ PEU } & PEU3 & & & & & .819 & & & & \\
\hline & PEU2 & & & & & .809 & & & & \\
\hline & PEU5 & & & & & .752 & & & & \\
\hline & PEU4 & & & & & .735 & & & & \\
\hline & PEU1 & & & & & .473 & & & & \\
\hline \multirow{4}{*}{ PUS } & PUS2 & & & & & & .895 & & & \\
\hline & PUS1 & & & & & & .891 & & & \\
\hline & PUS3 & & & & & & .890 & & & \\
\hline & PUS4 & & & & & & .685 & & & \\
\hline \multirow{5}{*}{ ATT } & ATT5 & & & & & & & .933 & & \\
\hline & ATT4 & & & & & & & .930 & & \\
\hline & ATT3 & & & & & & & .907 & & \\
\hline & ATT1 & & & & & & & .904 & & \\
\hline & ATT2 & & & & & & & .868 & & \\
\hline \multirow{4}{*}{ BEH } & $\mathrm{BEH} 3$ & & & & & & & & .912 & \\
\hline & $\mathrm{BEH} 4$ & & & & & & & & .895 & \\
\hline & BEH1 & & & & & & & & .869 & \\
\hline & $\mathrm{BEH} 2$ & & & & & & & & .851 & \\
\hline \multirow{4}{*}{$\mathrm{AC}$} & $\mathrm{AC} 4$ & & & & & & & & & .890 \\
\hline & AC3 & & & & & & & & & .875 \\
\hline & $\mathrm{AC} 2$ & & & & & & & & & .870 \\
\hline & $\mathrm{AC} 1$ & & & & & & & & & .817 \\
\hline \multicolumn{2}{|c|}{ KMO } & .739 & .685 & .631 & .689 & .789 & .727 & .876 & .846 & .835 \\
\hline \multicolumn{2}{|c|}{ Bartlett's Test (sig) } & .000 & .000 & .000 & .000 & .000 & .000 & .000 & .000 & .000 \\
\hline \multicolumn{2}{|c|}{ Eigen value } & 2.290 & 2.138 & 1.809 & 2.202 & 2.654 & 2.856 & 4.128 & 3.112 & 2.983 \\
\hline \multicolumn{2}{|c|}{ Cumulative } & 57.254 & 71.256 & 60.312 & 73.35 & 53.075 & 71.388 & 82.569 & 77.793 & 74.587 \\
\hline
\end{tabular}

EFA results of Privacy, Kaiser-Meyer-Olkin (KMO) value is 0.762 which is sufficient. Bartlett's test is an indication of strengthen of the relationship between the research variables. The cumulative variance is .572 (less than 0.6 , is some instances may happen (hair et al., 2010) and the four constructs are loaded into one component. Also, EFA results of Infrastructure indicate that $\mathrm{KMO}$ value is 0.685 which is sufficient, the cumulative variance

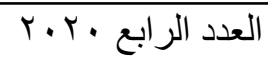

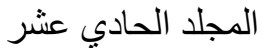


Factors Affecting Technology Acceptance During COVID-19 Crisis ...

Dr/ Niveen Ezzat Aly

is .712 and there are no cross loadings in component score coefficient matrix (hair et al., 2010), the three constructs are loaded into one component. EFA results of Institutional Support refer to that KMO value is 0.631 which is sufficient, the cumulative variance is .603 higher than 0.6), and there are no cross loadings in component score coefficient matrix (hair et al., 2010). EFA results of Access device indicate that KMO value is 0.689 which is sufficient, the cumulative variance is .733 and there are no cross loadings in component score coefficient matrix (hair et al., 2010), the three constructs are loaded into one component.

EFA results of Perceived Ease of Use indicate that KMO value is 0.789 which is sufficient, the cumulative variance is .530 (less than 0.6, is some instances may happen (hair et al., 2010), the five constructs are loaded into one component (had eigenvalue greater than 1). Also, EFA results of Perceived Usefulness refer to that $\mathrm{KMO}$ value is 0.727 , according to the cumulative variance is .713 (higher than 0.6), and there are no cross loadings in component score coefficient matrix (hair et al., 2010), the four constructs are loaded into one component (had eigenvalue greater than 1). EFA results of Attitude indicate that KMO value is 0 . 876 which is sufficient, the cumulative variance is .825 higher than (0.6), and there are no cross loadings in component score coefficient matrix (hair et al., 2010), the five constructs are loaded into one component (had eigenvalue greater than 1). EFA

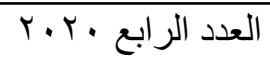$$
\text { المجلد الحادي عشر }
$$ 
Factors Affecting Technology Acceptance During COVID-19 Crisis ...

Dr/ Niveen Ezzat Aly

results of Behavioral intention refer to that $\mathrm{KMO}$ value is 0.846 which is sufficient, the cumulative variance is .777 higher than (0.6), and there are no cross loadings in component score coefficient matrix (hair et al., 2010), the four constructs are loaded into one component (had eigenvalue greater than 1), EFA results of The Actual Use indicate that KMO value is 0.835 which is sufficient, the cumulative variance is .745 higher than (0.6), and there are no cross loadings in component score coefficient matrix (hair et al., 2010), the four constructs are loaded into one component (had eigenvalue greater than 1).

\subsection{Reliability Analysis}

Before testing the proposed hypotheses, reliability analysis is performed to ensure the reliability of the variables. Cronbach's Alpha is used to test the reliability of the questions of the questionnaire as; it is the most common measure of scale reliability. The higher the score, the more reliable the generated scale is. Table (4) shows the reliability results based on Cronbach's alpha coefficients. 
Factors Affecting Technology Acceptance During COVID-19 Crisis ...

Dr/ Niveen Ezzat Aly

\begin{tabular}{|c|c|c|}
\hline \multicolumn{3}{|c|}{ Table (4): Reliability Results Based on Cronbach's Alpha Coefficien } \\
\hline \multicolumn{3}{|c|}{ Reliability Statistics } \\
\hline Construct & Items & Cronbach's Alpha \\
\hline \multirow{4}{*}{ Privacy } & PR1 & .780 \\
\hline & PR2 & .661 \\
\hline & PR3 & 654 \\
\hline & PR4 & 637 \\
\hline \multicolumn{2}{|c|}{ Cronbach's Alpha (Privacy) } & .747 \\
\hline \multirow{3}{*}{ Infrastructure } & INF1 & .681 \\
\hline & INF2 & 674 \\
\hline & INF3 & .804 \\
\hline \multicolumn{2}{|c|}{ Cronbach's Alpha (Infrastructure) } & .797 \\
\hline \multirow{3}{*}{ Institutional Support } & INS1 & .575 \\
\hline & INS2 & .665 \\
\hline & INS3 & .467 \\
\hline \multicolumn{2}{|c|}{ Cronbach's Alpha (Institutional Support) } & .670 \\
\hline \multirow{3}{*}{ Access Devices } & $\mathrm{ACC} 1$ & .689 \\
\hline & $\mathrm{ACC} 2$ & .716 \\
\hline & $\mathrm{ACC} 3$ & .831 \\
\hline \multicolumn{2}{|c|}{ Cronbach's Alpha (Access Devices) } & .817 \\
\hline \multirow{4}{*}{ Perceived Ease of Use } & PEU1 & .800 \\
\hline & PEU2 & .667 \\
\hline & PEU3 & .673 \\
\hline & PEU4 & .717 \\
\hline
\end{tabular}

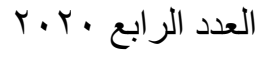

المجلد الحادي عشر 
Factors Affecting Technology Acceptance During COVID-19 Crisis ...

Dr/ Niveen Ezzat Aly

\begin{tabular}{|c|c|c|}
\hline & PEU5 & .709 \\
\hline \multicolumn{2}{|c|}{ Cronbach's Alpha (Perceived Ease of Use) } & .759 \\
\hline \multirow{4}{*}{ Perceived Usefulness } & PUS1 & .798 \\
\hline & PUS2 & .796 \\
\hline & PUS3 & .789 \\
\hline & PUS4 & .898 \\
\hline \multicolumn{2}{|c|}{ Cronbach's Alpha (Perceived Usefulness) } & .861 \\
\hline \multirow{5}{*}{ Attitude } & ATT1 & .936 \\
\hline & ATT2 & .944 \\
\hline & ATT3 & .935 \\
\hline & ATT4 & .928 \\
\hline & ATT5 & .927 \\
\hline \multicolumn{2}{|c|}{ Cronbach's Alpha (Attitude) } & .946 \\
\hline \multirow{4}{*}{ Behavioural intention } & BEH1 & .884 \\
\hline & $\mathrm{BEH} 2$ & .893 \\
\hline & BEH3 & .859 \\
\hline & BEH4 & .869 \\
\hline \multicolumn{2}{|c|}{ Cronbach's Alpha (Behavioural intention) } & .905 \\
\hline \multirow{4}{*}{ Actual Use } & $\mathrm{AC} 1$ & .877 \\
\hline & $\mathrm{AC} 2$ & .848 \\
\hline & $\mathrm{AC} 3$ & .846 \\
\hline & $\mathrm{AC} 4$ & .837 \\
\hline \multicolumn{2}{|c|}{ Cronbach's Alpha (Actual Use) } & .885 \\
\hline
\end{tabular}

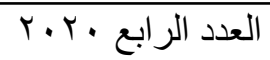


Factors Affecting Technology Acceptance During COVID-19 Crisis ...

Dr/ Niveen Ezzat Aly

With respect to the reliability test, all the constituent elements of the questionnaire can be reliable to test the hypotheses since they exceed the threshold 0.6 (Hair et al., 2010).

\subsection{Confirmatory Factor Analysis}

A systematic approach was taken to validate the proposed model (Hair et al., 2014). Convergent validity was assessed by examining the minimum requirements for factor loadings and the Average Variance Extracted (AVE) of the constructs. The convergence validity is measured as one of the criteria for evaluating the theoretical model for each variable separately.

Table (5): Measurement Model Evaluation and the Findings about Direct Paths

\begin{tabular}{|l|l|c|}
\hline Construct & AVE & CR \\
\hline Privacy & 0.570 & 0.838 \\
\hline Infrastructure & 0.712 & 0.881 \\
\hline Institutional Support & 0.598 & 0.879 \\
\hline Access Device & 0.708 & 0.879 \\
\hline Perceived Ease of Use & 0.529 & 0.843 \\
\hline Perceived Usefulness & 0.713 & 0.908 \\
\hline Attitude & 0.826 & 0.959 \\
\hline Behavioural intention & 0.778 & 0.933 \\
\hline Actual Use & 0.746 & 0.921 \\
\hline
\end{tabular}

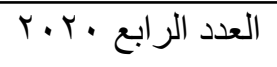

المجلد الحادي عشر 
Factors Affecting Technology Acceptance During COVID-19 Crisis ...

Dr/ Niveen Ezzat Aly

Table (5) indicated that all variables have Convergent validity of the theoretical model, given that their AVE coefficient is greater than 0.5 (Hair et al., 2014). Discriminant validity was evaluated on the basis of the Monotrait Ratio (HTMT) criterion (Henseler et al., 2015). All constructs met the $\mathrm{HTMT}_{0.85}$ criterion (the conservative criterion). Moreover, all constructs satisfied the recommended cut-off point for establishing composite reliability (CR) which is greater than 0.70 (Hair et al., 2014), where the CR of the constructs ranged between 0.80 and 0.95 .

Table (6): Discriminant Validity

\begin{tabular}{|c|c|c|c|c|c|c|c|c|c|}
\hline Construct & $\begin{array}{l}\text { Access } \\
\text { Device }\end{array}$ & $\begin{array}{c}\text { Actual } \\
\text { Use }\end{array}$ & Attitude & $\begin{array}{c}\text { Behavioural } \\
\text { intention }\end{array}$ & Infrastructure & $\begin{array}{c}\text { Institutional } \\
\text { Support }\end{array}$ & \begin{tabular}{|c|} 
Perceived \\
Ease of Use
\end{tabular} & $\begin{array}{l}\text { Perceived } \\
\text { Usefulness }\end{array}$ & Privacy \\
\hline Access Device & 0.841 & & & & & & & & \\
\hline Actual Use & 0.150 & 0.863 & & & & & & & \\
\hline Attitude & 0.216 & 0.486 & 0.909 & & & & & & \\
\hline $\begin{array}{c}\text { Behavioural } \\
\text { intention }\end{array}$ & 0.213 & 0.658 & 0.720 & 0.882 & & & & & \\
\hline Infrastructure & 0.530 & 0.145 & 0.242 & 0.162 & 0.844 & & & & \\
\hline $\begin{array}{c}\text { Institutional } \\
\text { Support } \\
\end{array}$ & 0.459 & 0.119 & 0.160 & 0.087 & 0.365 & 0.773 & & & \\
\hline $\begin{array}{c}\text { Perceived Ease } \\
\text { of Use }\end{array}$ & 0.155 & 0.451 & 0.547 & 0.479 & 0.226 & 0.073 & 0.727 & & \\
\hline $\begin{array}{l}\text { Perceived } \\
\text { Usefulness }\end{array}$ & 0.209 & 0.382 & 0.673 & 0.589 & 0.123 & 0.145 & 0.518 & 0.844 & \\
\hline Privacy & 0.311 & 0.094 & 0.245 & 0.227 & 0.469 & 0.222 & -0.166 & 0.113 & 0.755 \\
\hline
\end{tabular}

Table (6) indicated that the Measurement model all variables have discriminatory validity because extracted variance (AVE) is greater than covariance. Discriminant validity refer to the extent to which the scale used is able to distinguish the variable that it measures from the other variables in the study, in other words, to what extent the items loaded on each factor are related to this

$$
\text { العدد الر ابع • r. T }
$$

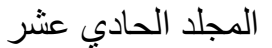


Factors Affecting Technology Acceptance During COVID-19 Crisis ...

Dr/ Niveen Ezzat Aly

factor only and not related to others, and it can be measured through the absence of a multiple load factor for any item on more than one factor.

\subsection{Model Fit indices}

Table (7): Model Fit indices

\begin{tabular}{|c|c|}
\hline Model of Fit Indices & Value \\
\hline NFI & 0.802 \\
\hline RMSE & 0.081 \\
\hline
\end{tabular}

Table (7) above indicated that NFI is 0.802 which means that this model is reasonable compatibility (0.80-0.90), Also, RMSE is 0.081 (less than 0.2) which means that this model is Very compatible.

\footnotetext{
العدد الرابع • r. T 
Factors Affecting Technology Acceptance During COVID-19 Crisis ...

Dr/ Niveen Ezzat Aly

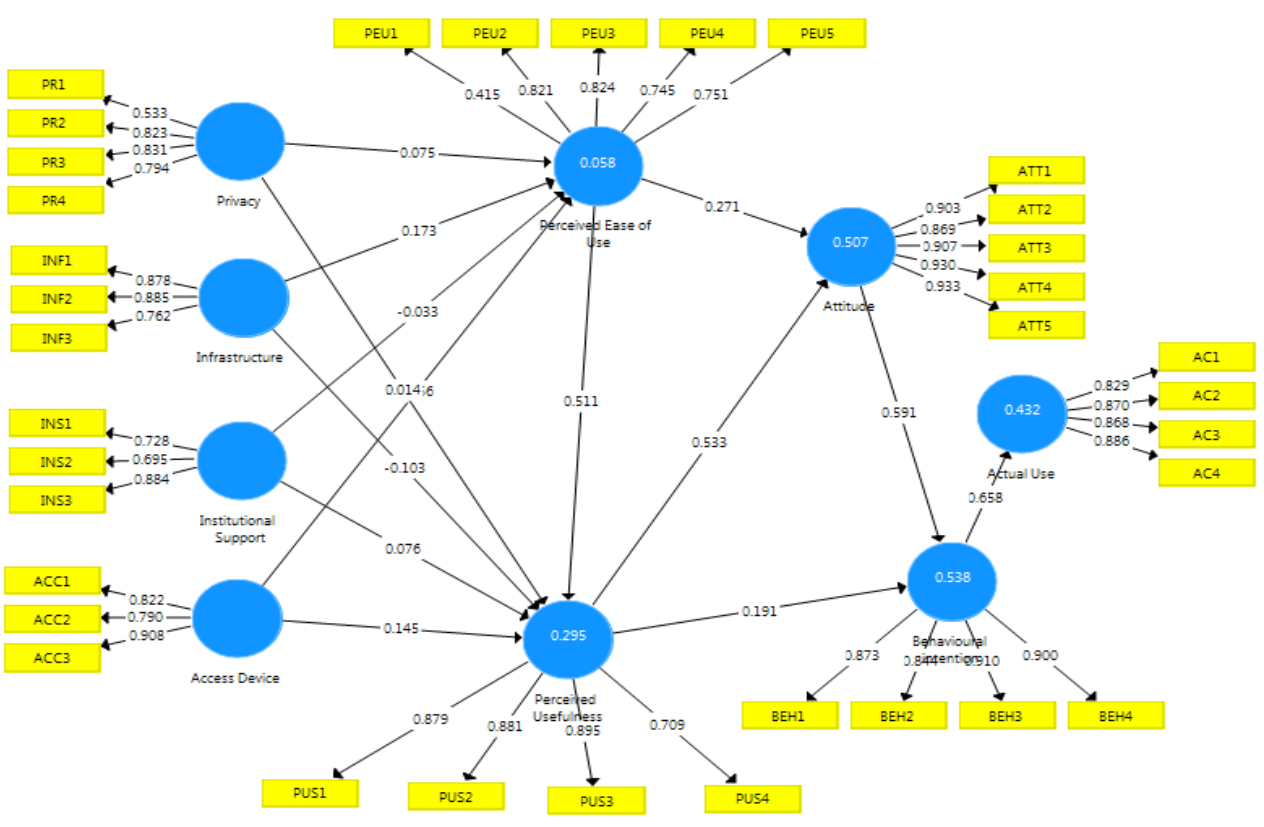

Figure (2): Measurement Model

\subsection{Path analysis}

The structural model explains $43.2 \%$ of the actual use of SNTs according to the influencing variables (perceived ease of use, perceived usefulness, attitude and behavioral intension). 
Factors Affecting Technology Acceptance During COVID-19 Crisis ...

Dr/ Niveen Ezzat Aly

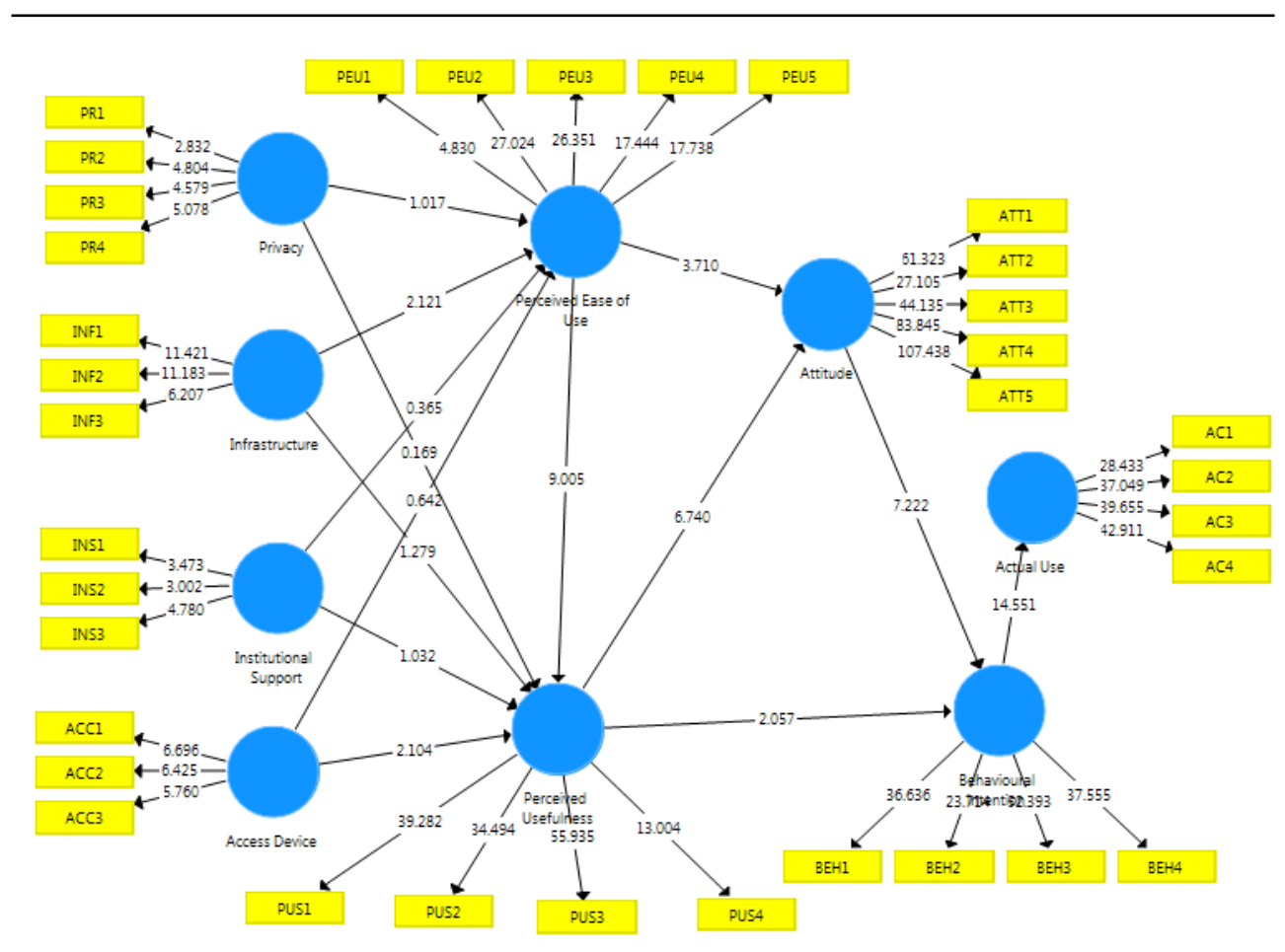

Figure (3): Structural Model

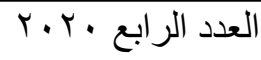

المجلد الحادي عثر 
Dr/ Niveen Ezzat Aly

Table (8): Hypothesis Test via Direct Effect

\begin{tabular}{|c|c|c|c|c|c|}
\hline \multirow[t]{2}{*}{ Hypothesis } & \multirow[b]{2}{*}{ Path } & \multicolumn{2}{|c|}{ Path coefficients } & \multirow{2}{*}{$\begin{array}{l}\text { Values } \\
\boldsymbol{\beta}_{(t \text {-value })} \text { sig. }\end{array}$} & \multirow[b]{2}{*}{ Decision } \\
\hline & & $\begin{array}{l}\text { Exogenous } \\
\text { Variable }\end{array}$ & $\begin{array}{c}\text { Endogenous } \\
\text { Variable }\end{array}$ & & \\
\hline H1 & $\begin{array}{l}\text { Privacy-> Perceived } \\
\text { Ease of Use }\end{array}$ & Privacy & $\begin{array}{l}\text { Perceived Ease } \\
\text { of Use }\end{array}$ & $0.075_{(1.017)}^{0.310}$ & Rejected \\
\hline $\mathrm{H} 2$ & $\begin{array}{l}\text { Privacy-> Perceived } \\
\text { Usefulness }\end{array}$ & Privacy & $\begin{array}{l}\text { Perceived } \\
\text { Usefulness }\end{array}$ & $0.014_{(0.169)}^{0.866}$ & Rejected \\
\hline $\mathrm{H} 3$ & $\begin{array}{l}\text { Infrastructure -> } \\
\text { Perceived Ease of Use }\end{array}$ & Infrastructure & $\begin{array}{l}\text { Perceived Ease } \\
\text { of Use }\end{array}$ & $0.173_{2.121}^{0.035)}$ & Supported* \\
\hline $\mathrm{H} 4$ & $\begin{array}{l}\text { Infrastructure -> } \\
\text { Perceived Usefulness }\end{array}$ & Infrastructure & $\begin{array}{l}\text { Perceived } \\
\text { Usefulness }\end{array}$ & $-0.103_{1.279^{0.201}}$ & Rejected \\
\hline H5 & $\begin{array}{l}\text { Institutional Support -> } \\
\text { Perceived Ease of Use }\end{array}$ & $\begin{array}{l}\text { Institutional } \\
\text { Support }\end{array}$ & $\begin{array}{l}\text { Perceived Ease } \\
\text { of Use }\end{array}$ & $-0.033_{0.365}^{0.716)}$ & Rejected \\
\hline H6 & $\begin{array}{l}\text { Institutional Support -> } \\
\text { Perceived Usefulness }\end{array}$ & $\begin{array}{l}\text { Institutional } \\
\text { Support }\end{array}$ & $\begin{array}{l}\text { Perceived } \\
\text { Usefulness }\end{array}$ & $0.076_{(1.032}^{0.302}$ & Rejected \\
\hline $\mathrm{H} 7$ & $\begin{array}{l}\text { Access Device -> } \\
\text { Perceived Ease of Use }\end{array}$ & Access Device & $\begin{array}{l}\text { Perceived Ease } \\
\text { of Use }\end{array}$ & $0.056_{(0.642)}^{0.521}$ & Rejected \\
\hline $\mathrm{H} 8$ & $\begin{array}{l}\text { Access Device -> } \\
\text { Perceived Usefulness }\end{array}$ & Access Device & $\begin{array}{l}\text { Perceived } \\
\text { Usefulness }\end{array}$ & $0.145_{(2.104)}^{0.036}$ & Supported* \\
\hline H9 & $\begin{array}{l}\text { Perceived Ease of Use-> } \\
\text { Attitude }\end{array}$ & $\begin{array}{l}\text { Perceived Ease } \\
\text { of Use }\end{array}$ & Attitude & $0.271_{(3.710)} 0.000$ & $\begin{array}{l}\text { Supported* } \\
* *\end{array}$ \\
\hline H10 & $\begin{array}{l}\text { Perceived Ease of Use-> } \\
\text { Perceived Usefulness }\end{array}$ & $\begin{array}{l}\text { Perceived Ease } \\
\text { of Use }\end{array}$ & $\begin{array}{l}\text { Perceived } \\
\text { Usefulness }\end{array}$ & $0.511_{(9.005)} 0.000$ & $\begin{array}{l}\text { Supported* } \\
* *\end{array}$ \\
\hline H11 & $\begin{array}{l}\text { Perceived Usefulness }-> \\
\text { Attitude }\end{array}$ & $\begin{array}{l}\text { Perceived } \\
\text { Usefulness }\end{array}$ & Attitude & $0.533_{(6.740)}^{0.000}$ & $\begin{array}{l}\text { Supported* } \\
* *\end{array}$ \\
\hline $\mathrm{H} 1^{\mathrm{r}}$ & $\begin{array}{l}\text { Perceived Usefulness-> } \\
\text { Behavioural intention }\end{array}$ & $\begin{array}{l}\text { Perceived } \\
\text { Usefulness }\end{array}$ & $\begin{array}{l}\text { Behavioural } \\
\text { intention }\end{array}$ & $0.191_{(\curlyvee .57)} 0.000$ & $\begin{array}{l}\text { Supported* } \\
* *\end{array}$ \\
\hline $\mathrm{H} 1^{\mathrm{T}}$ & $\begin{array}{l}\text { Attitude-> Behavioural } \\
\text { intention }\end{array}$ & Attitude & $\begin{array}{l}\text { Behavioural } \\
\text { intention }\end{array}$ & $0.591_{(7.222)}^{0.000}$ & $\begin{array}{l}\text { Supported* } \\
* *\end{array}$ \\
\hline $\mathrm{H} 1 \varepsilon$ & $\begin{array}{l}\text { Behavioural intention-> } \\
\text { Actual Use }\end{array}$ & $\begin{array}{l}\text { Behavioural } \\
\text { intention }\end{array}$ & Actual Use & $0.658_{(14.551)}{ }^{0.000}$ & $\begin{array}{l}\text { Supported* } \\
* *\end{array}$ \\
\hline
\end{tabular}

$* * *$ Confidence level is $99.9 \%, \mathrm{p}$ value $<0.001$, $\mathrm{t}$ value \pm 3.29 (for path coefficient only).

** Confidence level is $99 \%, \mathrm{p}$ value $<0.01, \mathrm{t}$ value \pm 2.58 (for path coefficient only).

* Confidence level is $95 \%, \mathrm{p}$ value $<0.05, \mathrm{t}$ value \pm 1.96 (for path coefficient only).

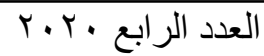


Factors Affecting Technology Acceptance During COVID-19 Crisis ...

Dr/ Niveen Ezzat Aly

As shown in Table (16), at a 95\% confidence level, $t$ - value \pm 1.96 , and $\mathrm{p}$ value $<0.05 \mathrm{H} 1, \mathrm{H} 2, \mathrm{H} 4, \mathrm{H} 5, \mathrm{H} 6$ and $\mathrm{H} 7$ were not accepted. Thus, H3, H8, H9, H10, H11, H12, H13 and H14 were all supported.

\section{Discussion}

One of the fundamental reasons for differences between the findings of this research and others may be due to the difference in the size of the sample and the research population, as only one faculty of Cairo University was included, Comprehensive Inventory Method was followed because the research population was 241 . Additionally, the characteristics of the faculty members in humanities' colleges - such as the Faculty of Commerce - differ from those in scientific colleges such as the School of Medicine, Engineering, and Sciences, also the environment in public and private universities is not alike. The results of this study showed that faculty members did not consider Privacy and Institutional Support as external factors affecting their acceptance of technology, in contradiction with the general trend in previous studies, where privacy is one of the strong influencing factors that may be one of the fundamental obstacles that limit the acceptance and the use of technology. The reason for this may be due to several considerations. Firstly, the culture of the Egyptian people is generally characterized by openness and love to participate personal details with others (family - relatives - friends, colleagues, and neighbors). Based on this, the concept of privacy is more flexible compared to other countries, even Arab ones (Sunny, S., Patrick,

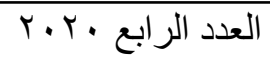

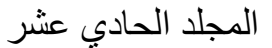


Factors Affecting Technology Acceptance During COVID-19 Crisis ...

Dr/ Niveen Ezzat Aly

L., \& Rob, L. (2019). Secondly, due to the recent application of the idea of using SNTs in teaching and the lack of past experience in this field, seeking help from others is necessary to understand and adopt the technology, this leads to being more open to sharing with colleagues and even with students (younger generation). That appears obviously with the elderly faculty members who spent all their previous years of experience relying only on the traditional face-to-face teaching method. Recent research concluded that according to the TAM model, the information needed as a mediator has an impact on employees' behavior in the workplace. The researchers emphasized the importance of interdisciplinary in the field of HRM and IT/IS (Zhang, Y., Luo, Y., Zhang, X., \& Zhao, J. (2019). Another reason for different research results could also be related to the nature of the circumstances in which the study was conducted. Where it was conducted during the period of the virus's spread, and it is known that crises may affect the behavior of individuals in the affirmative, so that condensation and cooperation occur between all of the stakeholders. The Egyptian people are characterized by a culture of support to others in times of crisis and a highly sense of responsibility and belonging towards their workplace. Faculty members are as well, the sense of belonging to the faculty administration and trust intensifies during the heat of the crisis, any effort made by management to help faculty members in facilitating dealing with distance education programs is met with appreciation and reverence. Recent research on TAM indicated

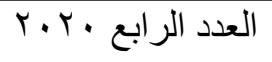

المجلد الحادي عشر 
Factors Affecting Technology Acceptance During COVID-19 Crisis ...

Dr/ Niveen Ezzat Aly

that trust positively influenced the behavioural intention of using and adopting Online technology (Chayomchai, A. (2020). Therefore, the researcher believes that the results of the study may be different if it was carried out under normal circumstances after the end of the crisis .

Institutional Support - also - has not been considered as one of the external factors affecting the acceptance and use of technology, and this is contrary to the majority of what previous studies have found. This may be due to several reasons ,the most important one- from the researcher's point of view- could be that faculty members throughout previous years have relied on their own experience to determine the appropriate method of teaching, bearing in mind that they have complete freedom and independence to choose the methods of explanation in the classroom which they think is appropriate from their point of view.

Infrastructure has partially affected the TAM, where the study proved that it has an effect on the perceived ease of use (in agreement with most of the literature), and at the same time it has no effect on the perceived usefulness (in contrast to most of the past studies). The reason for this may be due to the lack of the required infrastructure for this type of technology, whether at the university or faculty level, as the university recently started (after completing data collection) to establish the infrastructure to activate the use of the Blackboard platform and dependence on it in all activities and tasks associated with distance teaching-learning domain. Another

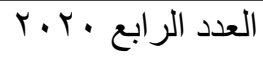

المجلد الحادي عشر 
Factors Affecting Technology Acceptance During COVID-19 Crisis ...

Dr/ Niveen Ezzat Aly

reason may be related to the Internet at the level of a developing country like Egypt and therefore at the level of the university or faculty campus. As it is known and obvious that in the period of the spread of the Covid 19 virus, the number of users and the number of hours of use has increased very significantly, and that was for all companies that provide Internet service in Egypt, which has negatively affected the efficiency and speed of the Internet and the coverage area .

Access Device was also partially affected the TAM, where the study proved that it has an effect on the perceived usefulness that was in the line of the past studies, and at the same time it has no effect on perceived ease of use. The reason for this may be the multiplicity of different types of devices that can be used and their differences in terms of ease of use, in addition to the fact that most technological developments aim to be a friendly user. Accordingly, the element of perceived usefulness is the most important factor that is significantly affected by the access device from the user's point of view.

\section{Limitations \& Future research}

First, the study was limited to only one faculty for reasons mentioned before, including all the faculties of Cairo University that would have increased the enrichment of the research and more comprehensive findings. Second, the study was restricted to one public university, studying a number of public, private, and

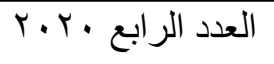

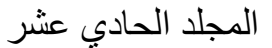


Factors Affecting Technology Acceptance During COVID-19 Crisis ...

Dr/ Niveen Ezzat Aly

international universities as well would have led to a better understanding of the characteristics of the higher education environment in Egypt. Third, the study duration was short, the questionnaire was available for only one month on Google Form. Many variables have occurred since the data collection was completed, and many decisions were taken, whether at the university or college level, again that would enrich and updated the research. Four, the small number of studies focusing on Egypt made the researcher adopt a study that took place in other Arab countries, despite the similarity of the language, the characteristics of the Egyptian environment and culture are vastly different. Therefore, many future studies that focus on Egypt are needed.

\section{Conclusion \& Recommendation}

The external factors affected the faculty members to use SNTs were odd to the majority of literature review. Higher education requires more attention from both researchers and policy makers to encourage the adoption of SNTs in teaching. Researchers' responsibility is to study the real factors that may hinder the use of SNTs, as well as to reach a solution to not waste the expertise and competencies of faculty members to improve the quality of education. The responsibility of the decision-makers lies in developing an integrated strategy that includes all the stakeholders, and reflects the reality of the Egyptian environment so that the quality of higher education can be promoted despite the challenges presented by the Covid-19 crisis.

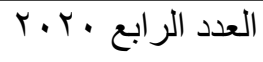

المجلد الحادي عشر 
Factors Affecting Technology Acceptance During COVID-19 Crisis ...

Dr/ Niveen Ezzat Aly

\section{References}

1. Abdullah, M. S., \& Toycan, M. (2017). Analysis of the factors for the successful e-learning services adoption from education providers' and students' perspectives: A case study of private universities in Northern Iraq. Eurasia Journal of Mathematics, Science and Technology Education, 14(3), 1097-1109.

2. Aburagaga, I., Agoyi, M., \& Elgedawy, I. (2020). Assessing Faculty's Use of Social Network Tools in Libyan Higher Education via a Technology Acceptance Model. IEEE Access, 8, 116415-116430.

3. Ahmed, S., \& Eltigani, B. (2020). Social Media in Teaching of Languages. International Journal of Emerging Technologies in Learning, 15(12).

4. AI-Youbi, A. O., Al-Hayani, A., Bardesi, H. J., Basheri, M., Lytras, M. D., \& Aljohani, N. R. (2020). The King Abdulaziz University (KAU) pandemic framework: a methodological approach to leverage social media for the sustainable management of higher education in crisis. Sustainability, 12(11), 4367.

5. Akbarilakeh, M., Razzaghi, A. and Moghaddam, H.D.P., 2019. Attitudes of faculty members towards using e-learning. Research and Development in Medical Education, 8(1), pp.12-19.

6. Al Kurdi, B., Alshurideh, M., \& Salloum, S. A. (2020). Investigating a theoretical framework for e-learning technology acceptance. International Journal of Electrical and Computer Engineering (IJECE), 10(6), 6484-6496. 
Factors Affecting Technology Acceptance During COVID-19 Crisis ...

Dr/ Niveen Ezzat Aly

7. ALABBADI, H., \& AL-MASAEED, S. U. L. T. A. N. (2020). THE IMPACT OF ICT ON CORONAVIRUS CRISIS MANAGEMENT. Journal of Theoretical and Applied Information Technology, 98(18).

8. Alharbi, S., \& Drew, S. (2014). Using the technology acceptance model in understanding academics' behavioural intention to use learning management systems. International Journal of Advanced Computer Science and Applications, 5(1), 143-155.

9. Ali, M. Y., \& Richardson, J. (2018). Usage of academic social networking sites by Karachi social science faculty: Implications for academic libraries. IFLA journal, 44(1), 23-34.

10. Almulhim, A. Y., Almulhim, S. A., Almulhim, A. A., \& Khan, A. S. (2020). The impact of e-learning modalities on medical students in KSA during the COVID-19 pandemic. Journal of Taibah University Medical Sciences, 15(5), 437-438.

11. Al-Okaily, M., Alqudah, H., Matar, A., Lutfi, A., \& Taamneh, A. (2020). Dataset on the Acceptance of e-learning System among Universities Students' under the COVID-19 Pandemic Conditions. Data in Brief, 32, 106176.

12. Al-Qaysi, N., Mohamad-Nordin, N., \& Al-Emran, M. (2020). A systematic review of social media acceptance from the perspective of educational and information systems theories and models. Journal of Educational Computing Research, 57(8), 2085-2109. 
Factors Affecting Technology Acceptance During COVID-19 Crisis ...

Dr/ Niveen Ezzat Aly

13. Aparicio-Martínez, P., Ruiz-Rubio, M., Perea-Moreno, A. J., MartínezJiménez, M. P., Pagliari, C., Redel-Macías, M. D., \& Vaquero-Abellán, M. (2020). Gender differences in the addiction to social networks in the Southern Spanish university students. Telematics and Informatics, 46, 101304.

14. Atabek, O., 2020. Alternative certification candidates' attitudes towards using technology in education and use of social networking services: a comparison of sports sciences and foreign language graduates. World Journal on Educational Technology: Current Issues, 12(1), pp.1-12.

15. Bao, W. (2020). COVID-19 and online teaching in higher education: A case study of Peking University. Human Behavior and Emerging Technologies, 2(2), 113-115.

16. Binyamin, S. S., Rutter, M., \& Smith, S. (2019). Extending the technology acceptance model to understand students' use of learning management systems in Saudi higher education. International Journal of Emerging Technologies in Learning (iJET), 14(03), 4-21.

17. Boin, A., Lodge, M., \& Luesink, M. (2020). Learning from the COVID-19 crisis: an initial analysis of national responses. Policy Design and Practice, 1-16.

18. Bylieva, D., Bekirogullari, Z., Lobatyuk, V., \& Nam, T. (2020) Analysis of The Consequences of The Transition to Online Learning on The Example of MOOC Philosophy During The COVID-19 Pandemic, Humanities \& Social Sciences Reviews eISSN: 2395-6518, Vol 8, No 4, 2020, pp1083-1093 https://doi.org/10.18510/hssr.2020.84103

19. Capano, G. (2020). Policy design and state capacity in the COVID-19 emergency in Italy: if you are not prepared for the (un) expected, you can be only what you already are. Policy and Society, 39(3), 326-344.

العدد الر ابع • r.

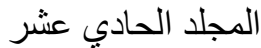


Factors Affecting Technology Acceptance During COVID-19 Crisis ...

Dr/ Niveen Ezzat Aly

20. Chayomchai, A. (2020). The Online Technology Acceptance Model of Generation-Z People in Thailand during COVID-19 Crisis. Management \& Marketing. Challenges for the Knowledge Society, 15(s1), 496-512.

21. Currie, G., Hewis, J., Nelson, T., Chandler, A., Nabasenja, C., Spuur, K., ... \& Kilgour, A. (2020). COVID-19 impact on undergraduate teaching: Medical radiation science teaching team experience. Journal of Medical Imaging and Radiation Sciences.

22. El Essawi, N. (2018). Students E-learning Acceptance: An Empirical Study through Extending Technology Acceptance Model in the Education Sector. Journal of the Faculty of Commerce for Scientific Research, 55 (2).

23. Eldin, A. Y. S. (2020). Faculty Members' Behavior towards Technology Acceptance and its Impact on a Value-Added Configuration. INTERNATIONAL JOURNAL OF ACADEMIC RESEARCH IN BUSINESS AND SOCIAL SCIENCES, 10(3).

24. Encyclopedia of Education and Information Technologies. (2020). Encyclopedia of Education and Information Technologies. Springer International Publishing. https://doi.org/10.1007/978-3-03010576-1

25. Garcia, E., Moizer, J., Wilkins, S., \& Haddoud, M. Y. (2019). Student learning in higher education through blogging in the classroom. Computers \& Education, 136, 61-74.

26. Granić, A., \& Marangunić, N. (2019). Technology acceptance model in educational context: A systematic literature review. British Journal of Educational Technology, 50(5), 2572-2593.

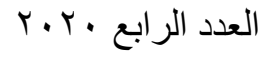

المجلد الحادي عشر 
Factors Affecting Technology Acceptance During COVID-19 Crisis ...

Dr/ Niveen Ezzat Aly

27. Greenhow, C., \& Chapman, A. (2020). Social distancing meet social media: digital tools for connecting students, teachers, and citizens in an emergency. Information and Learning Sciences.

28. Hsiao, C. C. (2020). Understanding content sharing on the internet: test of a cognitive-affective-conative model. Online Information Review.

29. https://www.igi-global.com/dictionary/social-networking-tools/27446

30. Khodabandeh, F., 2020. The Effect of Social Network Use on EFL Learners' Second Language Achievement: An Investigation into their Attitudes. IAU International Journal of Social Sciences, 10(1).

31. Kompen, R. T., Edirisingha, P., Canaleta, X., Alsina, M., \& Monguet, J. M. (2019). Personal learning Environments based on Web 2.0 services in higher education. Telematics and Informatics, 38, 194-206.

32. Kumar, V., \& Nanda, P. (2020). Social Media as a Tool in Higher Education: A Pedagogical Perspective. In Handbook of Research on Diverse Teaching Strategies for the Technology-Rich Classroom (pp. 239-253). IGI Global.

33. Magraner, J.S.B. and Ramos, R.L., 2020. INSTAGRAM AS A MUSICAL LEARNING TOOL IN SECONDARY EDUCATION AND HIGH SCHOOL. Vivat Academia, 23(151), pp.25-44.

34. Manalo, T. A., Higgins, M. I., Pettitt-Schieber, B., Pettitt, B. J., Mehta, A., \& Hartsell, L. M. (2020). How I Do It: A Strategy for Undergraduate Medical Education in Urology During the COVID-19 Pandemic. Journal of Surgical Education.

35. Manca, S. (2020). Snapping, pinning, liking or texting: Investigating social media in higher education beyond Facebook. The Internet and Higher Education, 44, 100707.

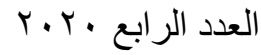

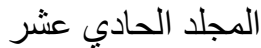


Factors Affecting Technology Acceptance During COVID-19 Crisis ...

Dr/ Niveen Ezzat Aly

36. Manca, S., \& Ranieri, M. (2017). Implications of social network sites for teaching and learning. Where we are and where we want to go. Education and Information Technologies, 22(2), 605-622.

37. Matemba, E. D., Li, G., Gogan, I. C. W., \& Maiseli, B. J. (2020). Technology acceptance model: recent developments, future directions, and proposal for hypothetical extensions. International Journal of Technology Intelligence and Planning, 12(4), 315-348.

38. McGee, E. (2020). Exploring Occupational Therapy Faculty Beliefs Related to Technology Acceptance of High-Fidelity Simulation.

39. Mishra, L., Gupta, T., \& Shree, A. (2020). Online Teaching-Learning in Higher Education during Lockdown Period of COVID-19 Pandemic. International Journal of Educational Research Open, 100012.

40. Mitroff, I. I., \& Pearson, C. M. (1993). Crisis management: A diagnostic guide for improving your organization's crisis-preparedness. Jossey-Bass.

41. Mohamed, N., \& Ahmad, I. H. (2012). Information privacy concerns, antecedents and privacy measure use in social networking sites: Evidence from Malaysia. Computers in Human Behavior, 28(6), 23662375.

42. Murillo, G. G., Novoa-Hernández, P., \& Rodríguez, R. S. (2020). Technology Acceptance Model and Moodle: A systematic mapping study. Information Development, 0266666920959367.

43. Oyetade, K. E., Harmse, A., \& Zuva, T. (2020, August). Technology Adoption Factors in Education: A Review. In 2020 International Conference on Artificial Intelligence, Big Data, Computing and Data Communication Systems (icABCD) (pp. 1-10). IEEE. 
Factors Affecting Technology Acceptance During COVID-19 Crisis ...

Dr/ Niveen Ezzat Aly

44. Pal, D., \& Vanijja, V. (2020). Perceived Usability Evaluation of Microsoft Teams as an Online Learning Platform During COVID-19 using System Usability Scale and Technology Acceptance Model in India. Children and Youth Services Review, 105535.

45. Podsiad, M., \& Havard, B. (2020). Faculty acceptance of the peer assessment collaboration evaluation tool: a quantitative study. Educational Technology Research and Development, 1-27.

46. Rahimi, B., Nadri, H., Afshar, H. L., \& Timpka, T. (2018). A systematic review of the technology acceptance model in health informatics. Applied clinical informatics, 9(3), 604.

47. Scherer, R., Siddiq, F., \& Tondeur, J. (2019). The technology acceptance model (TAM): A meta-analytic structural equation modeling approach to explaining teachers' adoption of digital technology in education. Computers \& Education, 128, 13-35.

48. Sepulveda-Escobar, P., \& Morrison, A. (2020). Online teaching placement during the COVID-19 pandemic in Chile: challenges and opportunities. European Journal of Teacher Education, 1-21.

49. Sharma, H. and Pillai, S.P. (2017), "Social media technology management in College of Technology in Oman: An empirical analysis", Journal of International Education in Business, Vol. 10 No. 2, pp. 147-163. https://doi.org/10.1108/JIEB-09-2016-0029

50. Sobaih, A. E. E., Moustafa, M. A., Ghandforoush, P., \& Khan, M. (2016). To use or not to use? Social media in higher education in developing countries. Computers in Human Behavior, 58, 296-305. 
Factors Affecting Technology Acceptance During COVID-19 Crisis ...

Dr/ Niveen Ezzat Aly

51. Vanduhe, V. Z., Nat, M., \& Hasan, H. F. (2020). Continuance Intentions to Use Gamification for Training in Higher Education: Integrating the Technology Acceptance Model (TAM), Social Motivation, and Task Technology Fit (TTF). IEEE Access, 8, 2147321484.

52. YAMANI, D., MOUHOUCHE, A., \& EL DJOUDI, A. A. (2019). Training in the use of Information and Communication Technologies in Education: impact on the attitude of the teacher. Educational Journal of the University of Patras UNESCO Chair.

53. Zarafshani, K., Solaymani, A., D’Itri, M., Helms, M. M., \& Sanjabi, S. (2020). Evaluating technology acceptance in agricultural education in Iran: A study of vocational agriculture teachers. Social Sciences \& Humanities Open, 2(1), 100041.

54. Zhang, Y., Luo, Y., Zhang, X., \& Zhao, J. (2019). How green human resource management can promote green employee behavior in China: A technology acceptance model perspective. Sustainability, 11(19), 5408 . 